\title{
Facile Use of ZnO Nanopowders to Protect Old Manual Paper Documents
}

\author{
Ludmila Motelica ${ }^{1}$, Aurelian Popescu ${ }^{2}$, Anca-Gabriela Răzvan ${ }^{1}$, Ovidiu Oprea ${ }^{1, * \mathbb{D}}$, \\ Roxana-Doina Truşcă ${ }^{1}$, Bogdan-Stefan Vasile ${ }^{1}$ (D) , Florina Dumitru ${ }^{1}$ (D) and Alina-Maria Holban ${ }^{3}$ \\ 1 Faculty of Applied Chemistry and Material Science, University POLITEHNICA of Bucharest, \\ 060042 Bucharest, Romania; motelica_ludmila@yahoo.com (L.M.); anca_razvan@yahoo.com (A.-G.R.); \\ truscaroxana@yahoo.com (R.-D.T.); bogdan.vasile@upb.ro (B.-S.V.); florina.dumitru@upb.ro (F.D.) \\ 2 Department of Publications Restoration and Preservation, "Carol I" Central University Library, \\ 010292 Bucharest, Romania; aurelian.popescu@bcub.ro \\ 3 Microbiology \& Immunology Department, Faculty of Biology, University of Bucharest, \\ 077206 Bucharest, Romania; alina.m.holban@bio.unibuc.ro \\ * Correspondence: ovidiu.oprea@upb.ro; Tel.: +40-02-1402-3986
}

Received: 2 November 2020; Accepted: 27 November 2020; Published: 30 November 2020

\begin{abstract}
One of the main problems faced by libraries, archives and collectors is the mold degradation of the paper-based documents, books, artworks etc. Microfungi (molds) emerge in regular storage conditions of such items (humidity, usually over $50 \%$, and temperatures under $21{ }^{\circ} \mathrm{C}$ ). If the removal of the visible mycelium is relatively easy, there is always the problem of the subsequent appearance of mold as the spores remain trapped in the cellulosic, fibrillary texture, which acts as a net. Moreover, due to improper hand hygiene bacteria contamination, old books could represent a source of biohazard, being colonized with human pathogens. An easy and accessible method of decontamination, which could offer long term protection is therefore needed. Here, we present a facile use of the $\mathrm{ZnO}$ nanopowders as antimicrobial agents, suitable for cellulose-based products, conferring an extended antibacterial and anti-microfungal effect. The proposed method does not adversely impact on the quality of the cellulose documents and could be efficiently used for biodegradation protection.
\end{abstract}

Keywords: $\mathrm{ZnO}$; paper; antimicrobial activity; long time protection; photocatalytic activity

\section{Introduction}

The life expectancy of collections is significantly affected by environmental storage conditions. Improper storage conditions for books or various documents on cellulosic or parchment paper can cause bacteria, fungi, or mold to grow on their surface [1]. The growth and multiplication of these pathogens leads to the production of digestive enzymes that alter and weaken the structure of the organic support, leading to the appearance of spots or even more severe degradation [2]. Spores eliminated by these pathogenic species also pose an important risk to human health. At present there are several possibilities for treating books in which sheets of paper or parchment have been degraded by bacteria, yeast and filamentous microfungi (molds). The support medium of the document can be brushed with a soft brush, vacuumed with HEPA (high-efficiency particulate air) system, or placed in a dry freezer. None of these methods ensures a deep removal of spores, nor does it provide a subsequent resistance of the document to pathogens. Another method used involves treatment with ethylene oxide or thymol, these substances being effective in removing the mold, but unfortunately, they are also carcinogenic [3].

At the individual level, some facile methods are applied, such as drying with a hairdryer, packing the document in a bag with rice or flour. These methods could only ensure the elimination of excess 
moisture absorbed by the cellulose support. Sodium bicarbonate packaging can be used to remove the odor generated by the present molds. None of these methods solves the problem of the existence of mold or its spores. If bacteria are present on a document, the owners usually do not even notice it as the manifestations are not as visible as in the case of molds [4]. Numerous bacterial species, especially gut-derived, present cellulose-degrading ability, similar to microfungi. Such microorganisms have cellulolytic potential and present metabolic degrading enzymes for cellulose containing foods, which reach in human digestive system [5]. Human opportunistic pathogens could colonize old books and cellulose based artworks by air-borne and improper hand hygiene contamination.

Two problems can be identified at this time, one economic and one technical. The methods currently used to process various records on cellulosic support or parchment (books, documents, official individual papers or from archives etc.) involve high cost equipment and require specialized staff. None of the current cleaning methods ensures a long-term protection of the cellulose based valuable products, requiring periodic interventions on the respective documents. In order to have a lasting antimicrobial effect, agents that provide antifungal and antibacterial activity must remain in contact with the cellulose product (i.e., document), without damaging it, and without representing a health hazard for the people who come in contact with the document.

The $\mathrm{ZnO}$ is one of the most studied nanomaterial, with applications in various domains, based on couple of its properties. Due to its high absorbance in the UV region, $\mathrm{ZnO}$ is commonly used as sunscreen [6], due to its intrinsic antimicrobial activity is used in the food industry and in medicine (also as drug delivery system) [7], and due to its transparent, semiconductor nature $\mathrm{ZnO}$ is used in optoelectronic devices [8], and finally as a pigment, $\mathrm{ZnO}$ is used in various paints or anticorrosion coatings [9]. The antibacterial activity of $\mathrm{ZnO}$ has been known for some time, but the antimycotic activity is seldom investigated [10-14]. The exact antimicrobial mechanisms is not known, but there are at least two separate pathways with respect to the light presence. The first mechanism implies photocatalytic activity, and perhaps reactive oxygen species (ROS) production, which is responsible for oxidative stress that is damaging the bacterial membrane. The second mechanism does not require light and is based on nanoparticle internalization and mechanical damage (like puncture and rupture) to the microorganism cellular wall [15-17].

Generally, ZnO nanoparticles (NPs) or bulk ZnO particulates, when used as antibacterial agents, are considered bio-safe within certain limits, which depend on the availability or concentration of zinc ions, but raise safety issues at higher concentrations [18], especially in nano form when ingested [19]. ZnO NPs have widespread use in cosmetics [20], various paints and coatings [9], active food packaging [21] and numerous biomedical applications [22], and thus, hazards from exposure via inhalation [23] and dermal exposure to them are of great concern and numerous studies have been carried out assessing their cytotoxicity when ingested or applied onto human skin [24-26]. The results are still controversial because of the information scarcity on human exposure assessment in realistic use [27], since the majority of studies were focused on the first two steps of risk assessment process; the intrinsic toxicity and dose-response relationship of ZnO NPs [28,29]. Although, ZnO NPs exhibited in vitro experiments oxidative stress-induced apoptosis in human lung epithelial cells (L-132) [23] or neurotoxic potential on neuronal cells [24], the cytotoxicity of ZnO NPs in these studies is evaluated at concentrations that are likely higher than would be expected for short-term exposure (topical or inhalation) [30]. There is widely accepted that ZnO NPs do not penetrate healthy human skin, even they do affect skin cells in vitro $[25,27]$. Furthermore, all in vivo and most in vitro genotoxicity tests were negative for $\mathrm{ZnO}$ NPs $[28,31,32]$.

Taking into account all these considerations, the current paper reports, the successful use of $\mathrm{ZnO}$ nanoparticles as antimicrobial agent, being efficient against common human opportunistic pathogens, including microfungi, which colonized old documents. When handling such old books, the users should anyway wear gloves, thus, limiting contact both, with pathogens and ZnO NPs, and in the absence of gloves the exposure time is relatively short. The $\mathrm{ZnO}$ nanoparticles were characterized by transmission electron microscopy (TEM), X-ray diffraction (XRD), ultraviolet-visible (UV-Vis) 
and photoluminescence (PL) spectroscopy. The photocatalytic and antibacterial activities were also determined. The paper samples treated with $\mathrm{ZnO}$ nanoparticles were investigated by UV-Vis and PL spectroscopy, Fourier transform infrared (FTIR) microscopy.

\section{Materials and Methods}

\subsection{Materials}

Zinc acetate dihydrate with 99.9\% purity was obtained from Merck (Merck Group, Darmstadt, Germany). The absolute ethanol was used as received from Sigma (Redox Lab Supplies Com SRL, Bucharest, Romania), without further purification. $\mathrm{ZnO}$ synthesis was done as described in [33]. Briefly, $2.1950 \mathrm{~g}$ zinc acetate dihydrate were solved in $50 \mathrm{~mL}$ absolute ethanol and heated under magnetic stirring at the boiling point. After $10 \mathrm{~h}$, the precipitate was washed and centrifugated three times, and the resulting powder was dried at $105^{\circ} \mathrm{C}$.

Two handmade paper sheets, from XVIII-XIX century, were received from "Carol I" Central University Library, Bucharest, and were noted as sample A (printed paper) and sample B (blanc paper). Each sheet was cut in strips to permit multiple analysis. Some of the paper strips were treated with $\mathrm{ZnO}$ by sprinkling minute quantities of nanopowder on the paper surface, followed by gentle brushing, with linear moves, by a soft brush with $50 \mathrm{~mm}$ long bristles. The excess powder was discarded by gentle tapping.

\subsection{Characterization of $\mathrm{ZnO}$ Nanoparticles and Paper Samples}

The transmission electron images for $\mathrm{ZnO}$ nanoparticles were obtained on dried, finely powdered samples using a Tecnai G2F30 S-TWIN high-resolution transmission electron microscope from FEI (FEI Company, Eindhoven, The Netherlands), operated at an acceleration voltage of $300 \mathrm{kV}$ obtained from a Schottky field emitter with a transmission electron microscope (TEM) point resolution of $2 \AA$ and line resolution of $1.02 \AA$.

Scanning electron micrographs for determination of the paper surface morphology and microstructure were obtained by using a QUANTA INSPECT F50, FEI Company, Eindhoven, The Netherlands scanning electron microscope equipped with field emission gun (FEG) with $1.2 \mathrm{~nm}$ resolution and an energy dispersive X-ray spectrometer (EDS, Thermo Fisher-formerly FEI, Eindhoven, The Netherlands) with an MnK resolution of $133 \mathrm{eV}$

In order to investigate the crystalline phases of the obtained nanopowder, the sample was analyzed using the PANalytical Empyrean equipment (from Malvern PANalytical, Bruno, The Nederland) using a Bragg-Brentano geometry, equipped with a $\mathrm{Cu}$ anode $\left(\lambda_{\mathrm{CuK \alpha}}=1.54184 \AA\right) \mathrm{X}$-ray tube and hybrid monochromator (Ge220). The X-ray diffractogram (XRD) was acquired in the $2 \theta$ range $10-75^{\circ}$. An acquisition step of $0.02^{\circ}$ and an acquisition time of 100 s per step were employed.

The photoluminescence spectrum (PL) was measured with a Perkin Elmer P55 (Perkin Elmer, Waltham, MA, USA) spectrometer using a Xe lamp as a UV light source at ambient temperature, in the range 350-600 nm, with the sample dried and finely powdered. The measurement was made with a scan speed of $200 \mathrm{~nm} \mathrm{~min}{ }^{-1}$, slit of $10 \mathrm{~nm}$, and cut-off filter of $1 \%$. An excitation wavelength of $320 \mathrm{~nm}$ was used.

Diffuse reflectance spectra measurements were made with a JASCO (Easton, PA, USA) V560 spectrophotometer with a solid sample accessory, in the domain $200-800 \mathrm{~nm}$, with a speed of $200 \mathrm{~nm} \mathrm{~min}^{-1}$.

The photocatalytic activity was determined against methylene blue (MB) $3.125 \times 10^{-5} \mathrm{M}(10 \mathrm{mg} / \mathrm{L})$ solution, by irradiation with a LOHUIS ${ }^{\circledR}$ (Ulmi, Romania), commercially available, fluorescent lamp of $160 \mathrm{~W} / 2900 \mathrm{~lm}$ (lumen), with color temperature of $3200 \mathrm{~K}$ and color rendering index >60, placed at $20 \mathrm{~cm}$ distance. The sample of $0.0250 \mathrm{~g}$ powder was inserted in $10 \mathrm{~mL}$ solution of MB and left under stirring for $30 \mathrm{~min}$ in dark to reach adsorption-desorption equilibrium. After irradiation, at 
defined time intervals, a sample of $3 \mathrm{~mL}$ was placed in a quartz $10 \mathrm{~mm}$ cuvette, and its UV-Vis spectra was recorded.

In order to obtain information about the spatial distribution of the $\mathrm{ZnO}$ nanoparticles on a paper surface, FTIR two-dimensional (2D) maps were recorded with a FTIR microscope Nicolet iS50R (Nicolet, Waltham, MA, USA), with DTGS detector, in the wavenumber range $4000-400 \mathrm{~cm}^{-1}$.

\subsection{Antimicrobial Evaluation}

\subsubsection{Antibacterial Activity}

Qualitative antibacterial activity of $\mathrm{ZnO}$ nanoparticles was tested against Gram-negative Salmonella typhimurium (ATCC 14028), Pseudomonas aeruginosa (ATCC 27853), Escherichia coli (ATCC 25922) and Gram-positive Staphylococcus aureus (ATCC 25923), Bacillus subtilis (ATCC 6633) and Enterococcus faecalis (ATCC 44479) bacteria, by drop inoculation on nutrient agar.

Briefly, the tested bacterial strains were swab inoculated on nutrient agar medium in Petri dishes and drops with a volume of $5 \mu \mathrm{L}$ of a $10 \mathrm{mg} / \mathrm{mL} \mathrm{ZnO}$ suspension were added. The Petri dishes were incubated $24 \mathrm{~h}$ at $37{ }^{\circ} \mathrm{C}$ and after that inhibition diameters were assessed. All experiments were designed and performed in triplicates.

\subsubsection{Microfungal (Mold) Removal}

In order to assess the ability of the obtained $\mathrm{ZnO}$ nanoparticles to remove molds colonizing cellulose-based products, samples of old paper from books presenting microfungal colonization and degradation were cut into pieces of $1 \mathrm{~cm} / 1 \mathrm{~cm}$ with sterile instruments to avoid external contamination. Then, some of the obtained old paper samples were treated with the $\mathrm{ZnO}$ nanoparticles, and some were used as control. The obtained specimens were used to inoculate PDA (potato dextrose agar) plates by a three-point inoculation method. Inoculated PDA was incubated in the dark for up to 7 days, at $20-22{ }^{\circ} \mathrm{C}$.

\section{Results and Discussion}

$\mathrm{ZnO}$ nanoparticles have been prepared in a non-basic route: a controlled solvolysis of $\mathrm{Zn}\left(\mathrm{CH}_{3} \mathrm{COO}\right)_{2} \cdot 2 \mathrm{H}_{2} \mathrm{O}$ in mild conditions (ethanol boiling temperature, no alkaline solution, water or other chemicals added) and therefore, the premises for their use in paper conservation are fully met. By weighting rectangular samples of paper (with various known dimensions) before, and after, applying $\mathrm{ZnO}$ nanopowder, we calculated that the retention of $\mathrm{ZnO}$ nanoparticles into the cellulosic support is on average $0.23 \pm 0.01 \mathrm{mg} / \mathrm{cm}^{2}$ on each side.

\subsection{Transmission Electron Microscopy (TEM)}

The TEM bright-field image obtained on $\mathrm{ZnO}$ nanoparticles synthesized by the solvothermal method is presented in Figure 1.

The Figure 1a-c images reveal that the powder is composed of polyhedral-shaped nanoparticles, with an average grain size of approximately $20 \mathrm{~nm}$, as can be observed from the histogram presented in Figure 2b. 


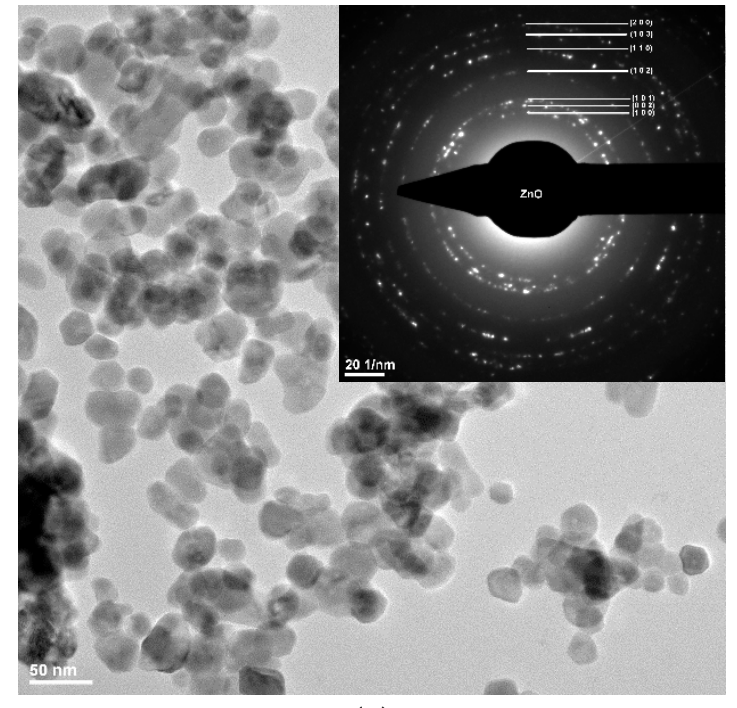

(a)

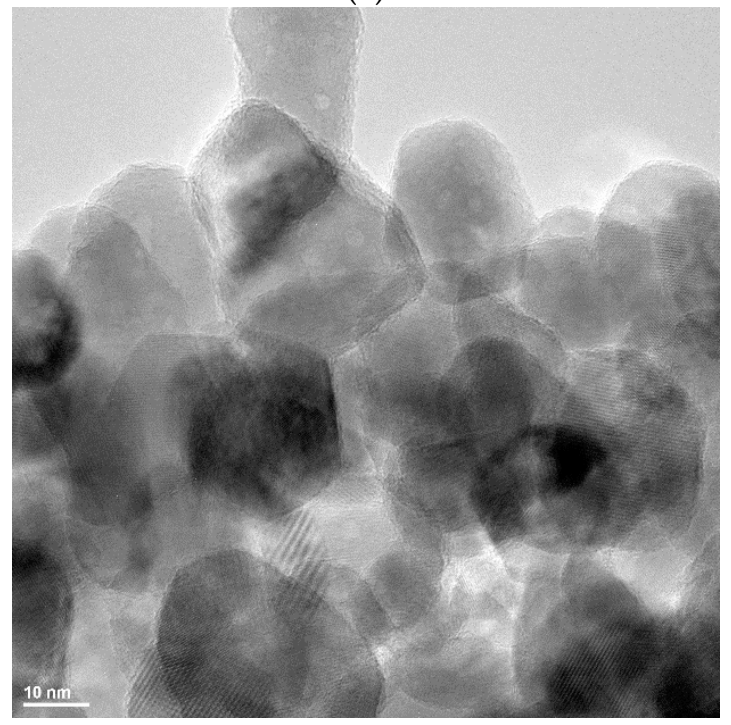

(c)

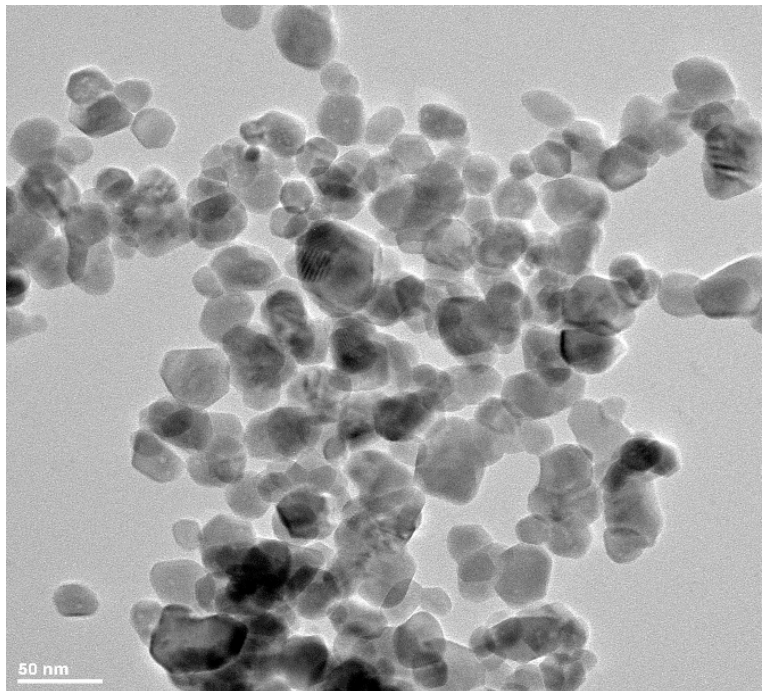

(b)

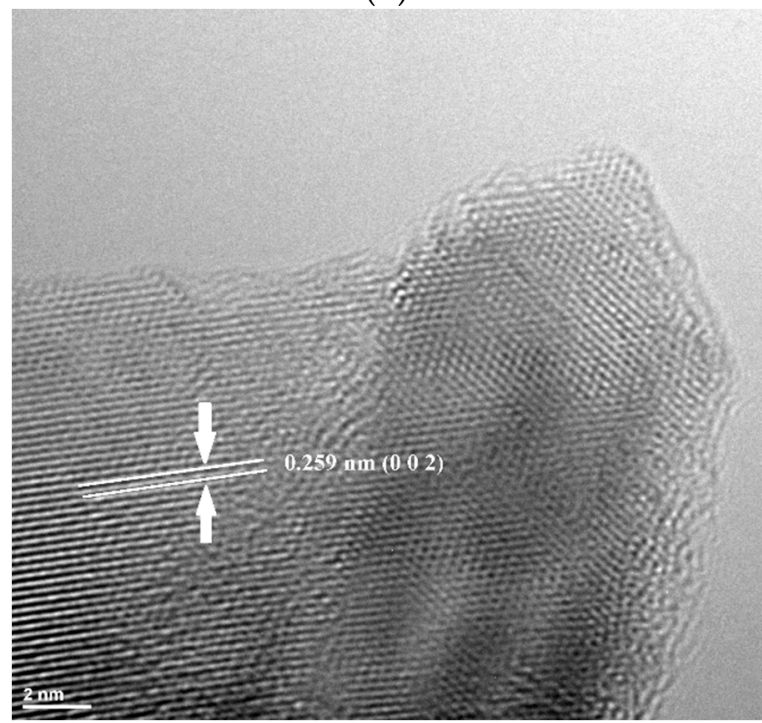

(d)

Figure 1. TEM $(\mathbf{a}-\mathbf{c})$ and high-resolution transmission electron microscopy (HRTEM) (d) images for $\mathrm{ZnO}$ nanoparticles.

The histogram was obtained by measuring about 500 nanoparticles, and only when they had clearly defined edges. The extreme values were discarded for statistical reason. Nevertheless, some nanoparticles have higher diameter of $\sim 30 \mathrm{~nm}$. The nanopowder also has the tendency to form some soft agglomerates. From the selected area diffraction (SAED) pattern obtained on $\mathrm{ZnO}$ nanopowder, we can state that the only phase identified is the polycrystalline hexagonal form of $\mathrm{ZnO}$ [JCPDS card no. 80-0075]. The high-resolution transmission electron microscopy (HRTEM) image obtained on nanocrystalline $\mathrm{ZnO}$ is shown in Figure $1 \mathrm{~d}$. The image shows clear lattice fringes of polycrystalline nanopowder of $d=2.59 \AA$ corresponding to the $\left(\begin{array}{ll}0 & 0\end{array}\right)$ crystallographic planes of $\mathrm{ZnO}$. Also, the regular succession of the atomic planes indicates that the nanocrystallites are structurally uniform and crystalline with no amorphous phase present.

Energy-dispersive X-ray spectroscopy (EDX) was used to determine the composition of the sample and the EDX pattern (Figure 2a) confirms that the isolated $\mathrm{ZnO}$ nanopowder is pure and contains only zinc and oxygen. 


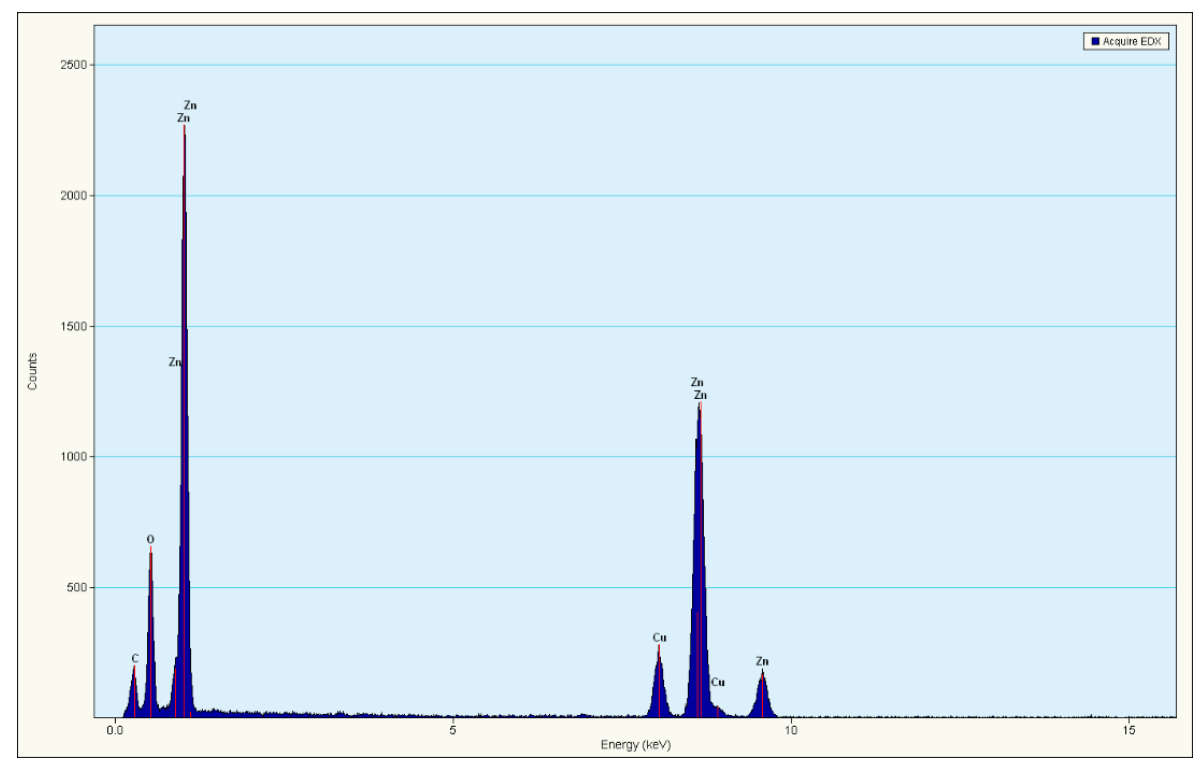

(a)

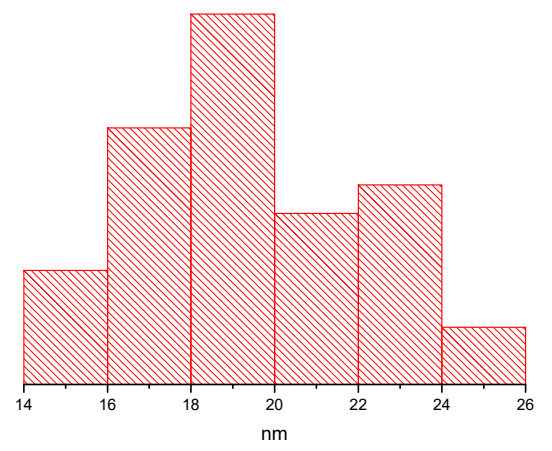

(b)

Figure 2. (a) EDX spectrum with $\mathrm{Zn} \mathrm{L} \alpha$ and $\mathrm{K} \alpha$ lines ( $\mathrm{Cu}$ lines are due to the copper grid used for placing the sample); (b) particle size distribution histogram.

\subsection{X-ray Powder Diffraction (XRD)}

Figure 3 presents the XRD pattern for $\mathrm{ZnO}$ nanopowder prepared by the solvothermal method.

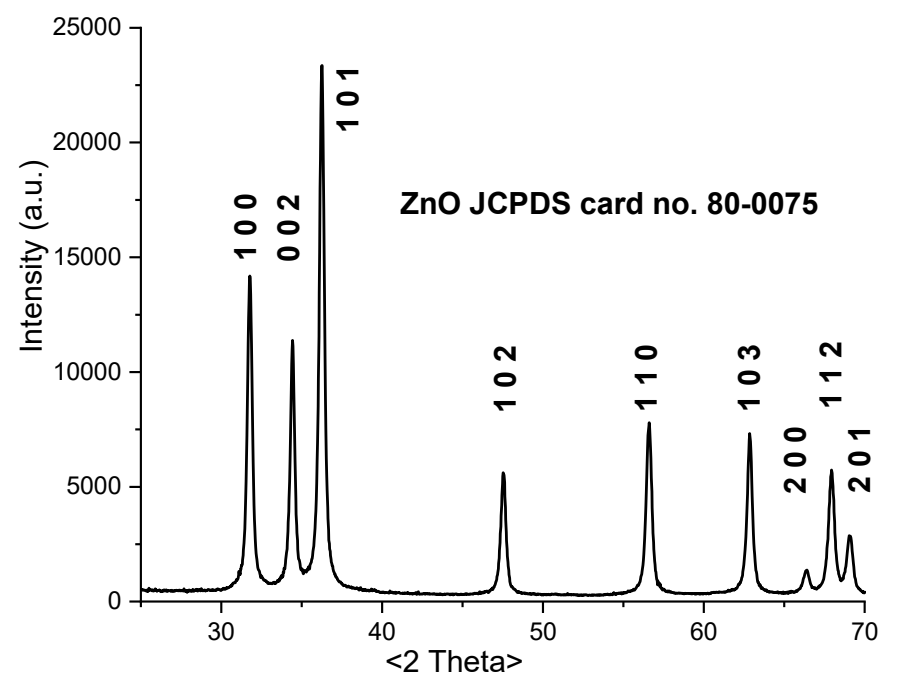

Figure 3. X-ray diffraction pattern for the $\mathrm{ZnO}$ nanoparticles. 
All the peaks correspond to the hexagonal, wurtzite, ZnO structure [JCPDS card no. 80-0075]. The XRD pattern indicates that the sample is pure and crystalline, with no second phase being identified.

The obtained XRD data was fitted by Rietveld refinement in order to determinate the crystallite size and microstrain. The obtained values are crystallite size $\mathrm{D}=26.75 \pm 3.03 \mathrm{~nm}$, and microstrain $\varepsilon=0.164 \pm 0.050 \%$. The crystallite average size is slightly larger than the TEM histogram value, due to statistical discard of outlier particles, but results suggest that each nanoparticle is composed of a single crystallite.

The lattice constant calculated for the ZnO nanoparticles are $a=b=3.2494 \AA$ and $c=5.2051 \AA$, with a ratio $c / a=1.6018$.

\subsection{UV-Vis and PL Spectrometry}

The electronic spectrum recorded for the $\mathrm{ZnO}$ nanopowder is presented in Figure 4a.

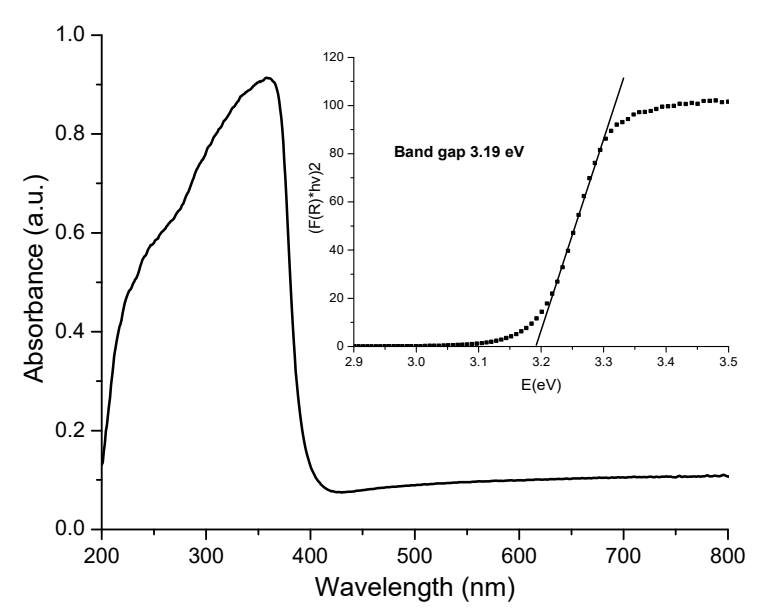

(a)

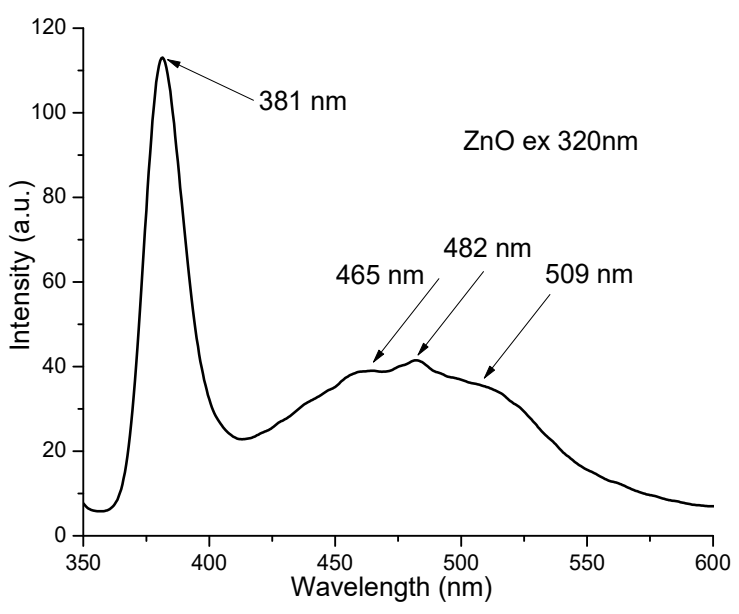

(b)

Figure 4. UV-Vis spectrum of $\mathrm{ZnO}$; (a) with band-gap determination (inset); fluorescence spectrum of $\mathrm{ZnO}$ for excitation wavelength $320 \mathrm{~nm}(\mathbf{b})$.

While, $\mathrm{ZnO}$ presents a very low absorption in visible region, the characteristic high intensity absorption band from UV regions present a maximum at $358 \mathrm{~nm}$. The fundamental absorption is related to the optical transition of electrons from valence band to conduction band and can be used to calculate the optical band gap of the $\mathrm{ZnO}$ nanopowder.

The diffuse reflectance of the sample, $R$, can be related to the Kubelka-Munk function $F(R)$ by relation, Equation (1):

$$
F(R)=(1-R)^{2} / 2 R \text {. }
$$

The direct band-gap energy value for the $\mathrm{ZnO}$ nanopowder was calculated from a plot of the square of the modified Kubelka-Munk function vs. energy (eV), the inset of Figure 4a. The value was determined to be $3.19 \mathrm{eV}$, by extrapolation to $[\mathrm{F}(\mathrm{R}) \cdot h v]^{2}=0$ [34]. The calculated band-gap energy is close to the theoretical value of $3.37 \mathrm{eV}$, but is smaller due to multiple defects that are inducing new electronic levels inside the $\mathrm{ZnO}$ band gap. Similar lower values are reported in literature by [35-38].

The recorded photoluminescence spectra of $\mathrm{ZnO}$ is presented in Figure $4 \mathrm{~b}$. Usually the $\mathrm{ZnO}$ nanopowders present two emission zones, one in UV and one in visible region. The UV emission corresponds to the near band edge emission (NBE) and is generated by the free exciton recombination. The sizeable binding exciton energy of the $\mathrm{ZnO}(60 \mathrm{meV})$ is responsible for the room temperature photoluminescence of $\mathrm{ZnO}$ [39]. The visible emission is usually referred as deep level emission (DLE) and is related to the existence of defect generated electronic levels inside the band gap (Figure 5). Calculating the ratio between the integrated area of NBE and DLE bands can be used to estimate the 
defect levels contribution. For high crystalline $\mathrm{ZnO}$ nanopowders the NBE is more intense than the DLE [40].

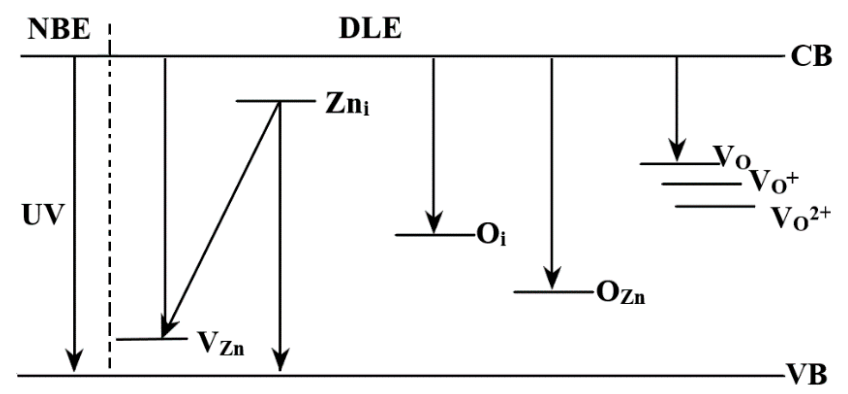

Figure 5. Defect's levels in ZnO nanoparticles; the UV emission is referred to as Near Edge Band (NBE), while the visible emission is caused by Deep Level Emission (DLE).

The $\mathrm{ZnO}$ crystal defects can be zinc vacancies $\left(\mathrm{V}_{\mathrm{Zn}}\right)$, zinc interstitials $\left(\mathrm{Zn}_{\mathrm{i}}\right)$, oxygen interstitials $\left(\mathrm{O}_{\mathrm{i}}\right)$, oxygen anti-sites $\left(\mathrm{O}_{\mathrm{Zn}}\right)$ or oxygen vacancies $\left(\mathrm{V}_{\mathrm{O}}\right)$ [41]. From these, oxygen vacancies are deep rather than shallow defects and can be involved, as recombination centers for green emission in $\mathrm{ZnO}$, with lower energy for $\mathrm{V}_{\mathrm{O}}$ site (placed upper in the band gap) and higher energy for $\mathrm{V}_{\mathrm{O} 2+}$ site. The surface excess oxygen or $-\mathrm{OH}$ moieties are acting as donor centers for the $\mathrm{V}_{\mathrm{O}}$ sites, and a weaker green emission indicates a lower surface defect concentration [42]. Zinc interstitials and zinc anti-sites are also shallow donors, but the last type requires a very high formation energy [43]. Zinc vacancies are deep acceptors and usually are related to the green and blue emissions. Oxygen interstitials are also deep acceptors with high formation energy (usually at octahedral interstitial site).

The obtained $\mathrm{ZnO}$ nanopowder has a strong NBE emission at $3.25 \mathrm{eV}(381 \mathrm{~nm})$, with peaks from DLE at $2.67 \mathrm{eV}(465 \mathrm{~nm}), 2.57 \mathrm{eV}$ (482 nm) and green emission at $2.43 \mathrm{eV}(509 \mathrm{~nm})$. This confirms the high crystallinity of the sample, as indicated by TEM and XRD. The $\mathrm{V}_{\mathrm{Zn}}$ are responsible for the emission in the violet region, transitions from $\mathrm{Zn}^{+}{ }_{\mathrm{i}}$ to valence band (VB) generate the $2.67 \mathrm{eV}(465 \mathrm{~nm})$ band, while transitions from $\mathrm{Zn}^{+}{ }_{\mathrm{i}}$ to $\mathrm{V}_{\mathrm{Zn}}$ are responsible for the $2.57 \mathrm{eV}(482 \mathrm{~nm})$ emission. The green emission from $2.43 \mathrm{eV}(509 \mathrm{~nm})$ and the further is generated mainly by $\mathrm{V}_{\mathrm{O}}$ and $\mathrm{V}_{\mathrm{O}+}$ defects [44].

\subsection{Photocatalytic Activity}

The photocatalytic activity of $\mathrm{ZnO}$ nanopowder is well-known [45-47], along with that of $\mathrm{TiO}_{2}[48,49]$, and the literature reports many investigations, due to possible links with antimicrobial activity and photoluminescence properties. We chose to investigate the photocatalytic activity against methylene blue (MB), as this is a phenothiazine dye and has the tendency to dimerize. Therefore, the photocatalytic activity is investigated against the monomer with absorption maximum at $664 \mathrm{~nm}$, but also vs the dimer with absorption maximum at $614 \mathrm{~nm}$.

The decrease of both absorption maxima, Figure 6, indicate that $\mathrm{ZnO}$ nanoparticles are capable to photodegrade both organic compounds.

For diluted solutions the photodegradation reactions exhibit apparent first-order kinetics, $\ln (\mathrm{C} 0 / \mathrm{C})$ $=k_{\mathrm{app}} \cdot \mathrm{t}$, where $\mathrm{C} 0$ is the initial concentration of $\mathrm{MB}, \mathrm{C}$ is the $\mathrm{MB}$ concentration at time $\mathrm{t}$ (hours) and $k_{\text {app }}$ is the rate constant of apparent first order. Similar first-order kinetics fitting are reported for $\mathrm{MB}$ degradation by $\mathrm{ZnO}$ in [50-52]. The calculated value for $k_{\text {app }}$ from the slope of the inset graphic is $0.2014 \pm 0.0192 \mathrm{~h}^{-1}$, with $\mathrm{R}$-square value of 0.940 . The values obtained for the rate constant are dependent on multiple factors, among which MB initial concentration and ZnO quantity. Comparable rate constant value is reported for concentration of $15 \mathrm{mg} / \mathrm{L} \mathrm{MB}$ and $75 \mathrm{mg}$ photocatalyst [51]. The same paper reports that decreasing the concentration to $10 \mathrm{mg} / \mathrm{L}$, while keeping the ZnO quantity at $75 \mathrm{mg}$, more than doubles the rate constant, while further decreasing the concentration to 5 ppm produce no significant changes. This suggest that the excessive coverage of catalyst surface with MB molecules can act as a light-barrier, and prevents the immediate degradation of adsorbed molecules [50]. For solution 
with $10 \mathrm{mg} / \mathrm{L} \mathrm{MB}$ put in contact with $50 \mathrm{mg}$ oxygen defect-rich $\mathrm{ZnO}$ under visible light irradiation, the reported $k$ value is $5.198 \times 10^{-3} \mathrm{~min}^{-1}\left(0.3118 \mathrm{~h}^{-1}\right)$, while for $\mathrm{ZnO}$ prepared by basic precipitation the $k$ value is $4.0337 \times 10^{-4} \mathrm{~min}^{-1}\left(0.0242 \mathrm{~h}^{-1}\right)$, which suggest that the oxygen defects plays also an important role in the photodegradation of the dye [53].

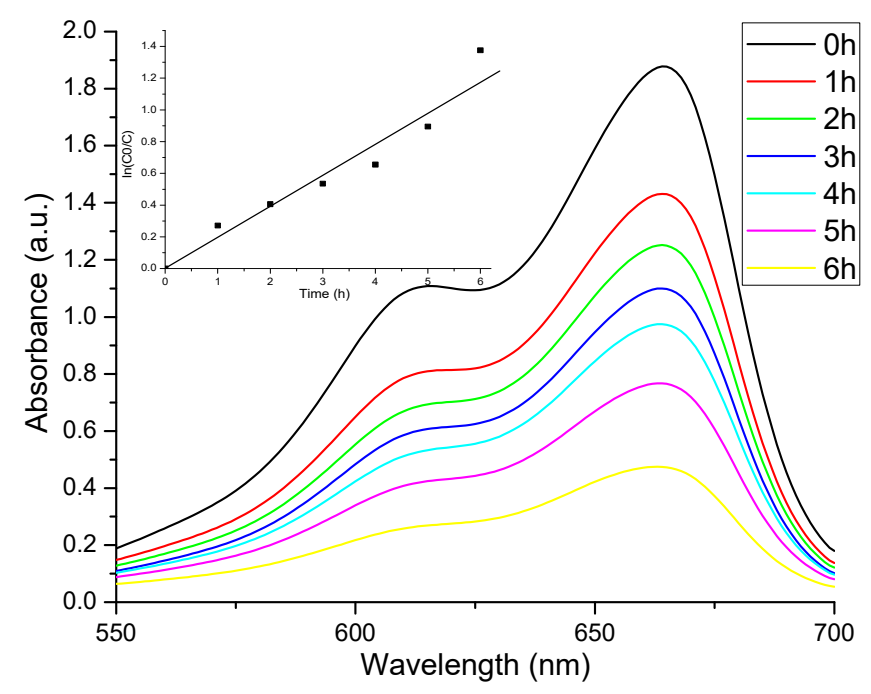

Figure 6. Photocatalytic activity against methylene blue (MB); the pseudo-first-order rate constant $k_{\text {app }}$ $\left(\mathrm{h}^{-1}\right)$ was calculated from the slope of $\ln (\mathrm{C} 0 / \mathrm{Ct})$ versus irradiation time $\mathrm{t}$.

As we mentioned the antibacterial mechanism of $\mathrm{ZnO}$ nanoparticles is still unclear, but it exhibit different activities in the presence of light and under dark [54]. In presence of light, reactive oxygen species (ROS) are generated and photocatalytic activity might be involved into the promotion of the antimicrobial activity. ROS are responsible of photocatalytic activity, but also for the oxidative stress which is damaging the bacterial membrane [55].

\subsection{Antimicrobial Activity}

Agar diffusion tests were performed as a qualitative rapid method to observe the $\mathrm{ZnO}$ nanoparticles antibacterial activity.

Antibacterial activity of $\mathrm{ZnO}$ nanoparticles was tested against opportunistic bacteria species, such as Gram-negative Salmonella typhimurium, Pseudomonas aeruginosa, Escherichia coli and Gram-positive Staphylococcus aureus, Bacillus subtilis and Enterococcus faecalis strains. The qualitative results presented in Figure 7, indicate a good antibacterial activity, the least susceptible being $P$. aeruginos a which is well known also for its low antibiotic susceptibility.

In numerous studies on the $\mathrm{ZnO}$ nanoparticles, antibacterial activity is correlated with different particle morphologies [56]. The shape-dependent activity is most probably related to the percent of active facets of the nanoparticles. As we obtained the polyhedral nanoparticles with size $\sim 20 \mathrm{~nm}$ the observed antibacterial activity is good, the $\mathrm{ZnO}$ nanoparticles being effective against a broad spectrum of bacterial strains. 


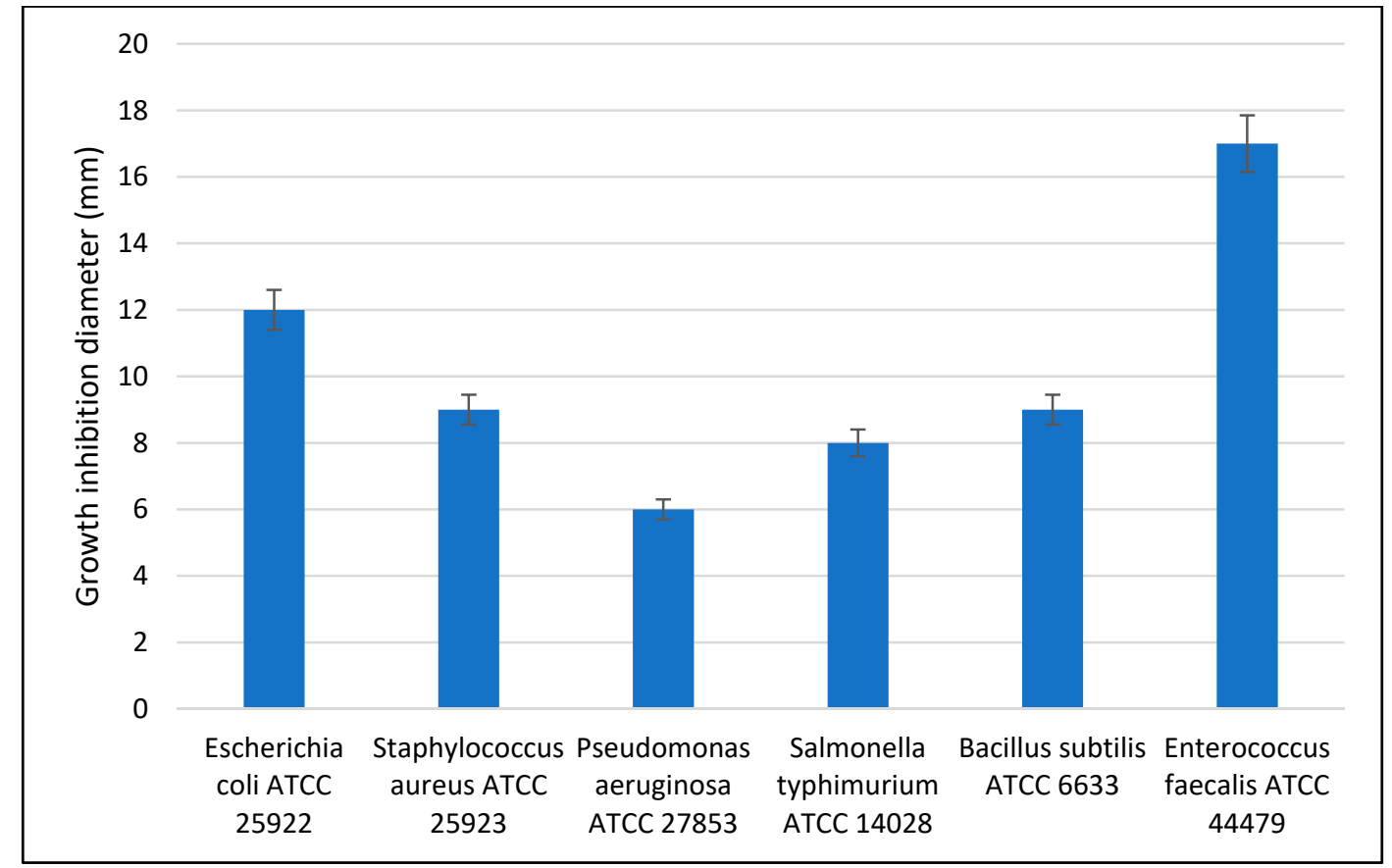

Figure 7. The antimicrobial activity of $\mathrm{ZnO}$ nanoparticles.

\subsection{Scanning Electron Microscopy (SEM) of Old Documents Paper}

The SEM micrographs for two paper samples (XVIII-XIX century) received from "Carol I" Central University Library are presented in Figure 8.

The images revealed the high infestation degree of these samples with various microorganisms (most of them belonging to Aspergillus sp.) [57]. In libraries, fungal growth known as mold or mildew affects paper, leather and textiles. Fungi consume cellulose and thrive on nutrients from gelatin size, collagen from leather, glues from binding etc. They can weaken and stain the paper, causing foxing, discoloration and in the end the destruction of the document support. Some bacterial strains also decompose the cellulose in paper and binding textiles [58].

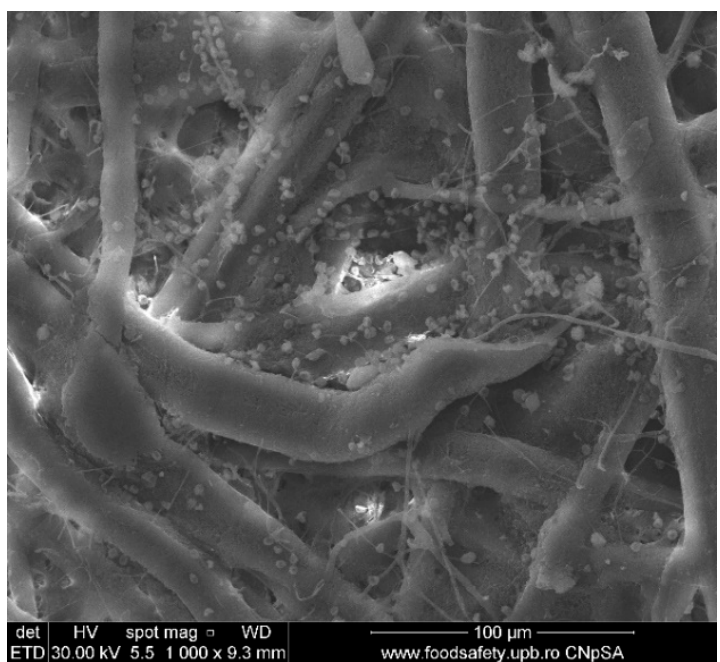

(a)

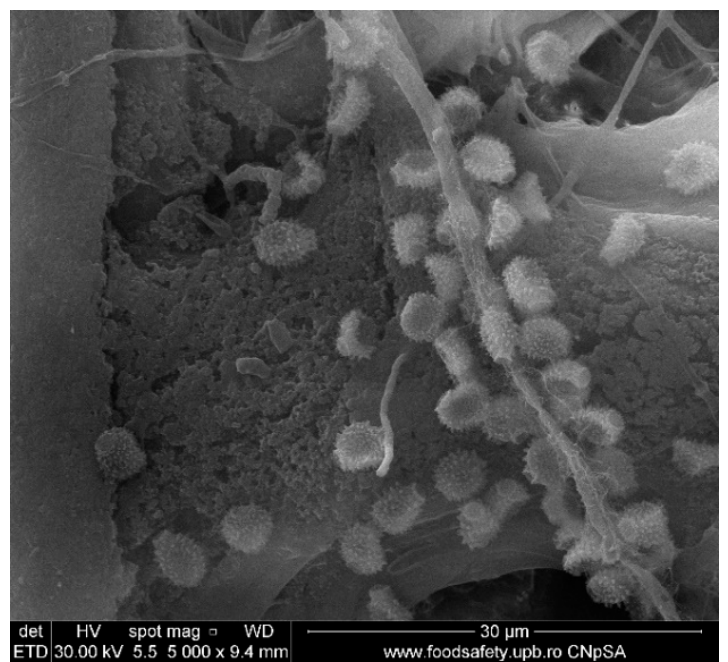

(b)

Figure 8. Cont. 


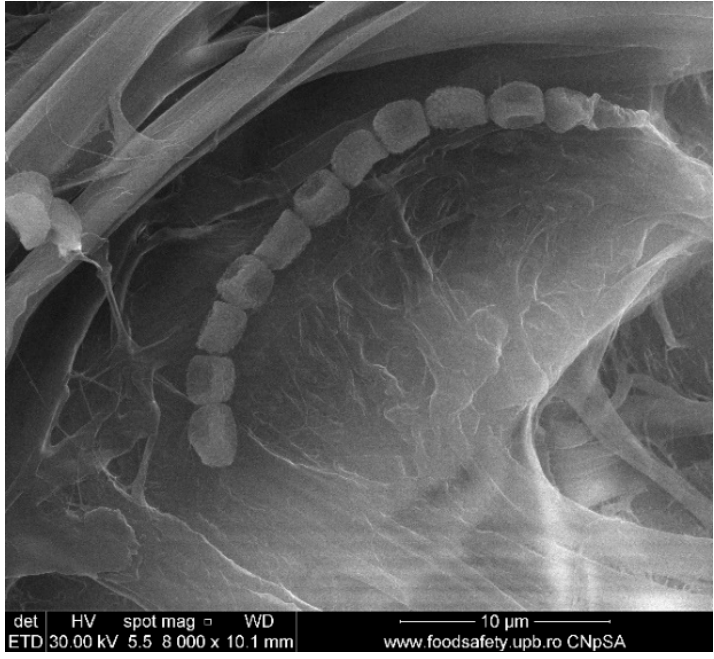

(c)

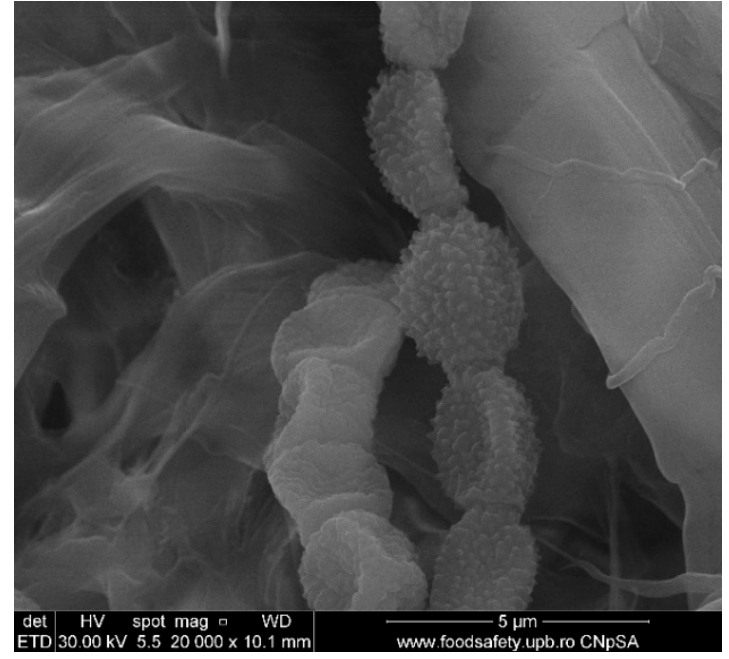

(d)

Figure 8. Different microorganisms found in paper sample A $(\mathbf{a}, \mathbf{b})$ and sample B (c,d).

The EDS elemental mapping images of the $\mathrm{ZnO}$ treated paper clearly indicate the uniform distribution of the $\mathrm{ZnO}$ nanoparticles on the surface (Figure 9).
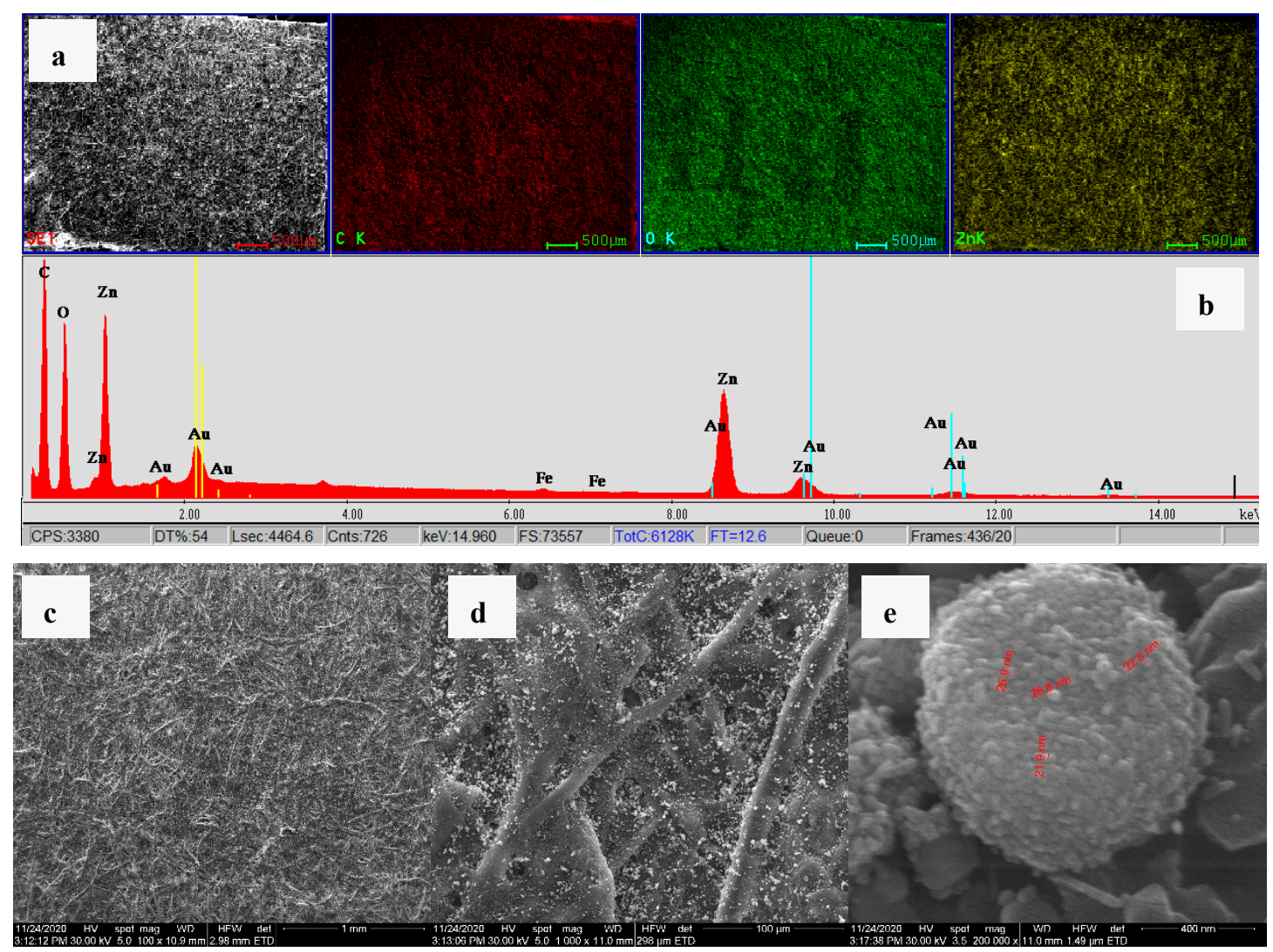

Figure 9. SEM and EDS elemental mapping for ZnO treated paper. SEM image (a) with elemental distribution: carbon-red; oxygen-green and zinc-yellow at 60×. Energy dispersive X-ray spectrum (b). EDX spectrum of the treated sample, with lines from $\mathrm{C}, \mathrm{O}$ and $\mathrm{Zn}$ as elements composing the sample (Au lines are due to conducting thin film deposition), (c) SEM image at 100× magnification, (d) SEM image at 1000 $\times$ magnification with clear $\mathrm{ZnO}$ agglomerates inside the fibrillar structure of paper, (e) SEM image at 200k $\times$ magnification with individual nanoparticles identification. 
The SEM images indicate that the $\mathrm{ZnO}$ nanoparticles formed small, spherical agglomerates that are presented among the cellulose fibers.

\subsection{FTIR Microscopy of Old Documents Paper}

Samples of $\sim 10 \mathrm{~mm} \times 10 \mathrm{~mm}$ were cut from the paper strips after $\mathrm{ZnO}$ application. The spatial distribution of $\mathrm{ZnO}$ nanoparticles on the paper surface after treatment was investigated by FTIR microscopy. The FTIR maps recorded at 430 and $1643 \mathrm{~cm}^{-1}$ for the two paper samples are presented in Figure 10. As Figure 10a indicate, the ink is clearly visible after applying the $\mathrm{ZnO}$ treatment.

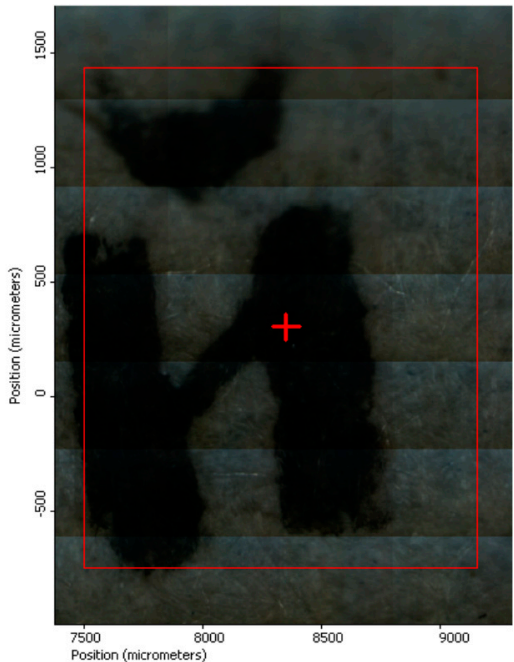

(a)

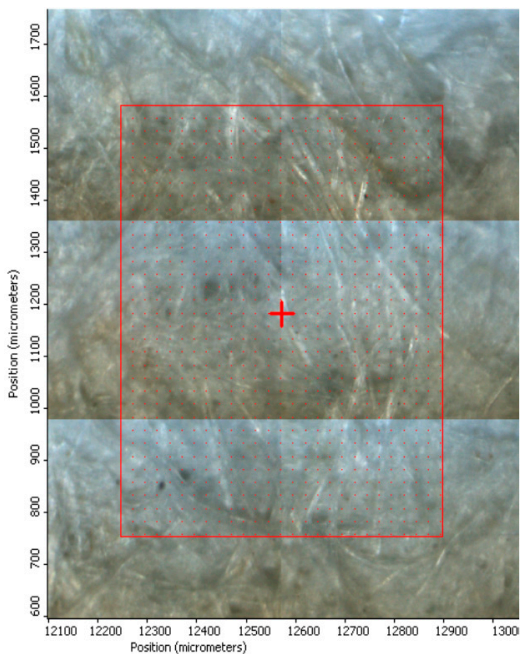

(d)

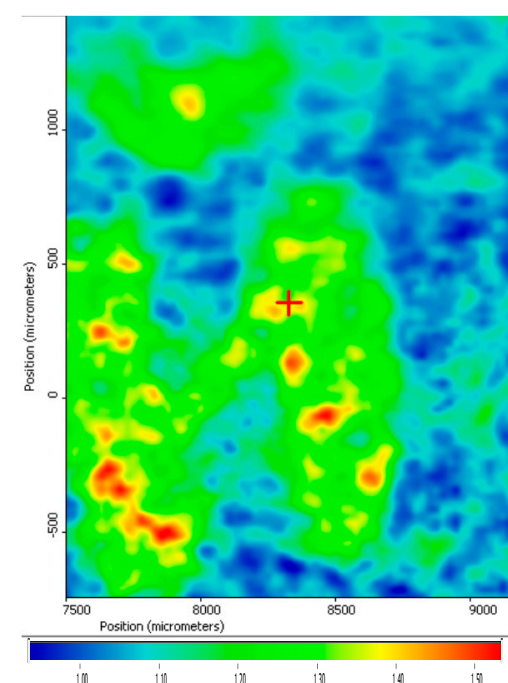

(b)

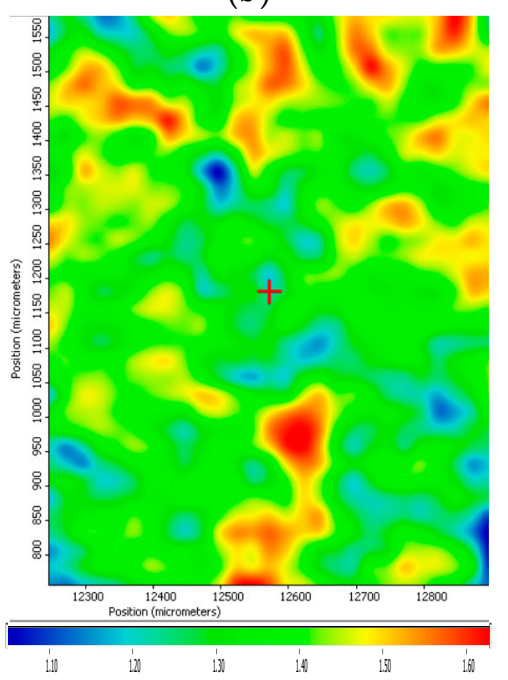

(e)

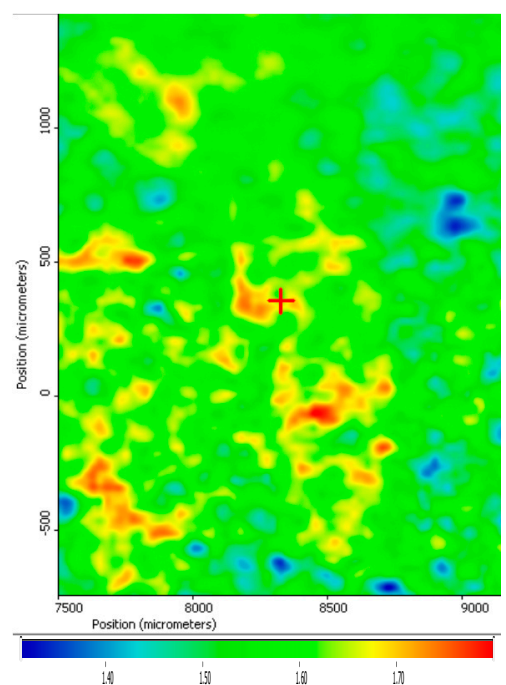

(c)

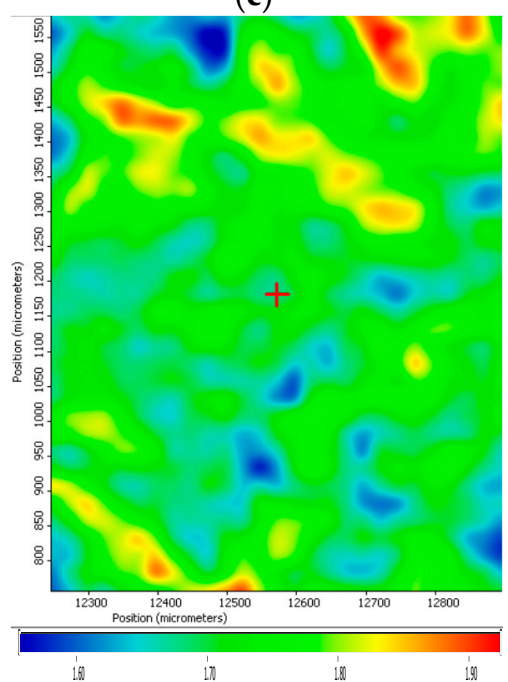

(f)

Figure 10. FTIR microscopy on sample A_ZnO (a-c) and sample B_ZnO (d-f): video image of paper (a,d); FTIR map at $1643 \mathrm{~cm}^{-1}$ (b,e); FTIR map at $430 \mathrm{~cm}^{-1}(\mathbf{c}, \mathbf{f})$.

The wavenumbers were chosen as they are characteristics for stretching vibration of $\mathrm{Zn}-\mathrm{O}$ bond $\left(430 \mathrm{~cm}^{-1}\right)$ and for $\mathrm{C}=\mathrm{O}$ stretching in amide I band $\left(1643 \mathrm{~cm}^{-1}\right)[59,60]$. The old paper manufacturing process required sizing of the paper surface with gelatin, hence the amide group presence [61]. The distribution of $\mathrm{ZnO}$ nanoparticles on the surface of the cellulosic material is quite homogenous, with occasional small agglomerated clusters/accumulations. There are some noticeable differences between the maps recorded at 430 and $1643 \mathrm{~cm}^{-1}$ for sample A_ZnO, which means that even if $\mathrm{ZnO}$ nanoparticles are homogeneously distributed on the sample surface (Figure 10c), the ink from the letter 
is still visible (as can be seen in Figure 10a,b). This indicate that after treating the paper, letters are clearly visible, while some $\mathrm{ZnO}$ nanoparticles are being obviously retained on the surface.

The FTIR maps for sample B_ZnO, Figure 10b,c, suggest also a homogeneously distribution of $\mathrm{ZnO}$ on the paper surface, with small zones in which are presented some agglomeration. The ZnO NPs most probably interact with cellulose fibrils via -OH moieties as indicated in $[62,63]$. The FTIR maps suggest that $\mathrm{ZnO}$ application method is successfully distributing the nanoparticles between cellulosic fibers, which also acts like a net, the quantities applied not interfering with ink visibility.

\subsection{UV-Vis and PL Ppectrometry on Old Documents Paper}

Strips from the samples A and B are presented in Figure 11, before, and after, treatment with ZnO nanoparticles. In order to better visualize the differences between the treated and untreated surface, the treatment was performed initially only in the selected areas. As can be observed, the paper became slightly whiter, and the foxing which was present on the sample A disappeared.
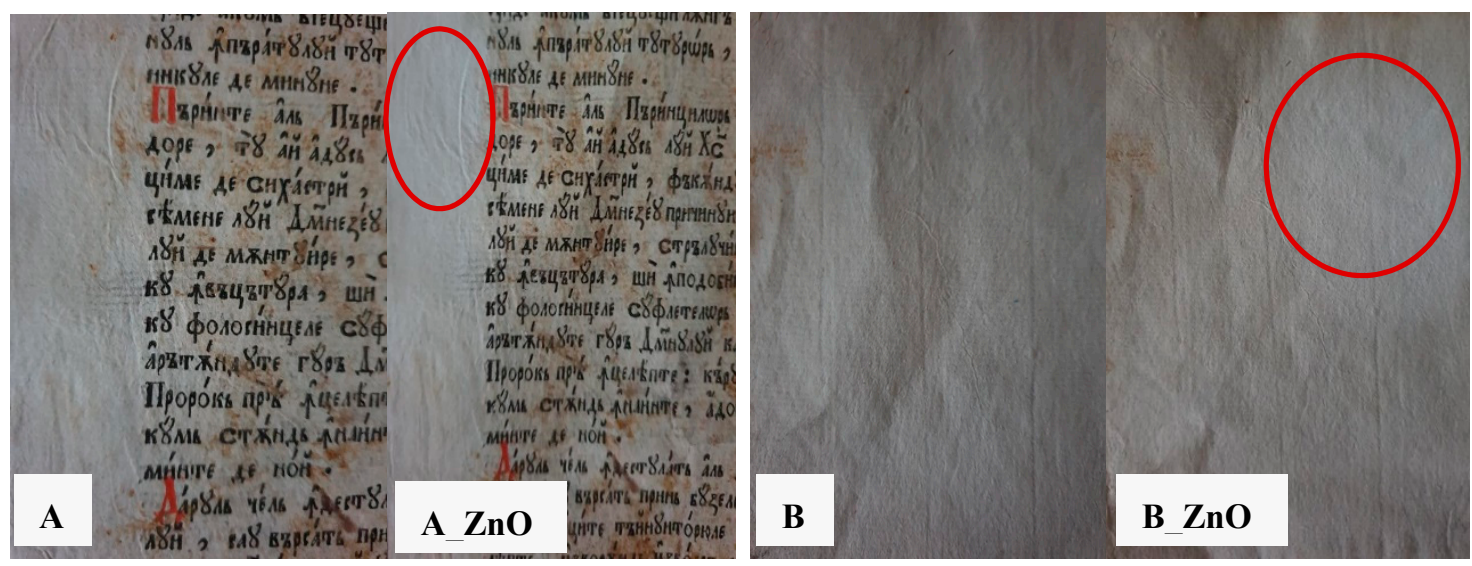

Figure 11. The original paper $\mathrm{A}$ and $\mathrm{B}$ and treated paper $\mathrm{A} \_\mathrm{ZnO}$ and $\mathrm{B} \_\mathrm{ZnO}$.

Both samples (A and B) were light yellow due to their old age and to the manufacturing process. The UV-Vis and PL spectra were recorded on areas indicated in Figure 11. The paper samples had quite different spectra in UV region, Figure 12, with absorption maxima at 220 and $322 \mathrm{~nm}$, indicating both different compositions and manufacturing processes.

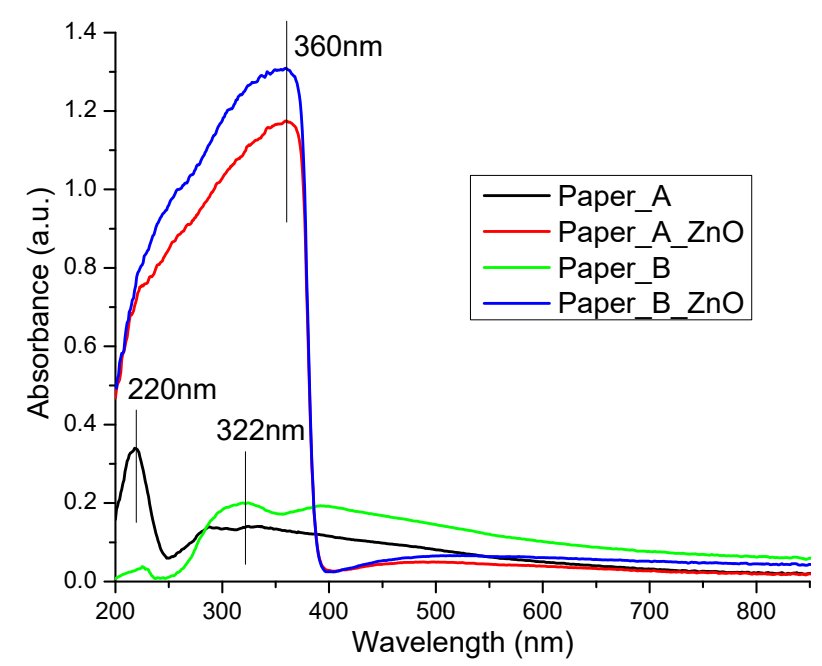

Figure 12. UV-Vis spectra for paper samples before and after $\mathrm{ZnO}$ treatment. 
For the samples treated with $\mathrm{ZnO}$ nanoparticles (A_ZnO and B_ZnO), both UV-Vis spectra are similar and present one broad, very intense absorption band in the UV region, with a maximum at $360 \mathrm{~nm}$. The shape of the UV-Vis spectra is attributed to the presence of $\mathrm{ZnO}$ nanoparticles on the paper's surface. Moreover, this indicates that $\mathrm{ZnO}$ nanoparticles can also act as a UV-barrier and effectively protect the paper from harmful UV radiation. The intensity of the absorption band is higher than the initial $\mathrm{ZnO}$ powder, indicating a good dispersion between cellulosic fibers and a good scattering of incoming radiation. The existence of some interactions between nanoparticles and fibrils, leading to the increase of absorbance, is also highlighted by the different intensities of A_ZnO and B_ZnO absorbances.

A whitening effect of treatment with $\mathrm{ZnO}$ nanoparticles of the samples is also observed in the visible region of spectra.

The photoluminescence spectra for treated and untreated samples are presented in Figure 13.

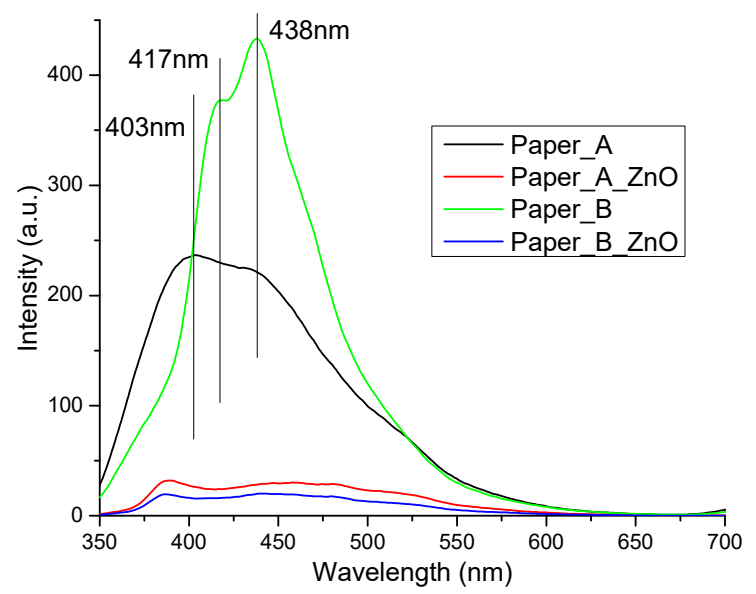

(a)

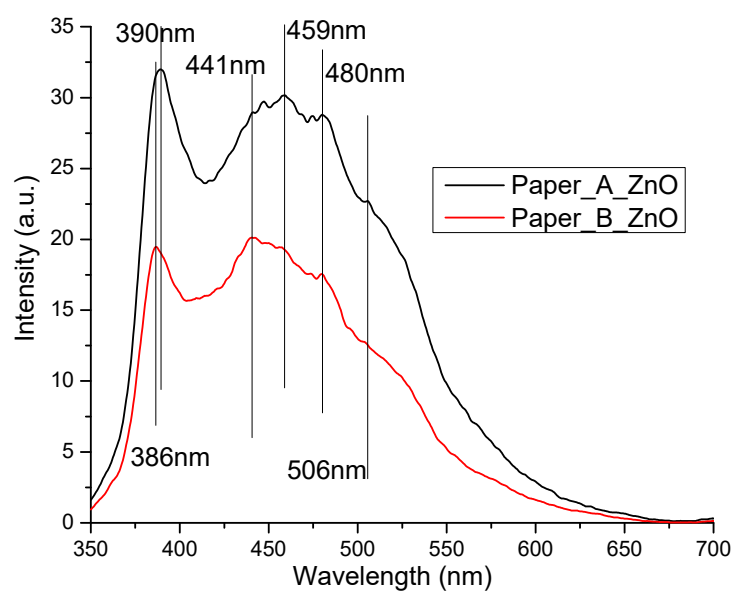

(b)

Figure 13. Photoluminescence spectra for paper samples before and after $\mathrm{ZnO}$ treatment (a); details of fluorescence spectra for $\mathrm{ZnO}$ treated paper (b).

The untreated manual paper had a high, characteristic blue fluorescence due to the presence of sizing gelatin $[64,65]$ and from cellulose fibrils $[66,67]$. Both samples present a large, intense, violet-blue emission band, with multiple peaks and a tail towards longer wavelengths.

As the fluorescence is generated by gelatin and cellulosic fibrils, the different ratios between components will modify the shape of the emission band. Moreover, the blue emission of cellulose is highly dependent on crystallinity degree, and manual papers present large variation between manufacturers, due to rags type and quality [68], and due to technology [69,70].

Surprisingly, the treated samples had a quenched fluorescence after $\mathrm{ZnO}$ nanoparticles entered into the cellulosic net. Despite the high fluorescence of $\mathrm{ZnO}$, the treated paper samples presented a few lower intensity emission bands. The NBE emission intensity was 3-6 times lower when compared with $\mathrm{ZnO}$ powder, while the DLE decreased by $25-50 \%$ only. $\mathrm{ZnO}$ nanoparticles can interact with -OH groups from cellulose fibrils. but also from collagen degradation products (gelatin) [71,72]. The same interactions between $\mathrm{ZnO}$ nanoparticles and cellulose fibrils that enhance the UV-band absorption intensity (in UV-Vis spectra, Figure 11) are responsible for the decrease of the fluorescence emission.

\subsection{Antimicrobial Assay for Paper Samples before and after Treatment with $\mathrm{ZnO}$}

Our results revealed that $\mathrm{ZnO}$ treatment of old book samples, with visible microfungi colonization and degradation, completely removes the colonizing species (both mycelia and spores). In paper-treated samples, the growth of microfungi was absent in PDA after 7 days of incubation in standard conditions. As expected, in untreated paper samples with mold colonization and biodegradation aspect, we have 
isolated multiple microfungal species, such as Aspergillus niger, Trichoderma sp. and Penicillium sp., which are known human opportunistic pathogens (Figure 14).

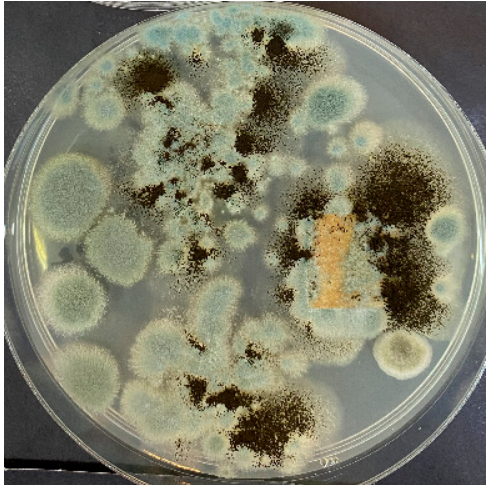

(a)

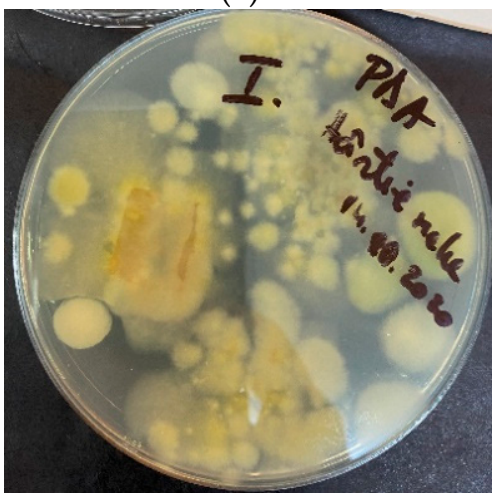

(d)

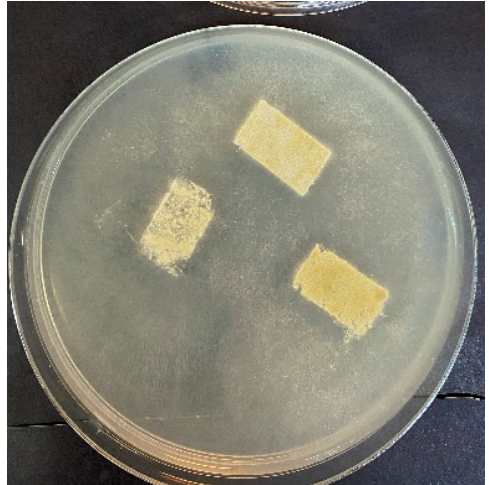

(b)

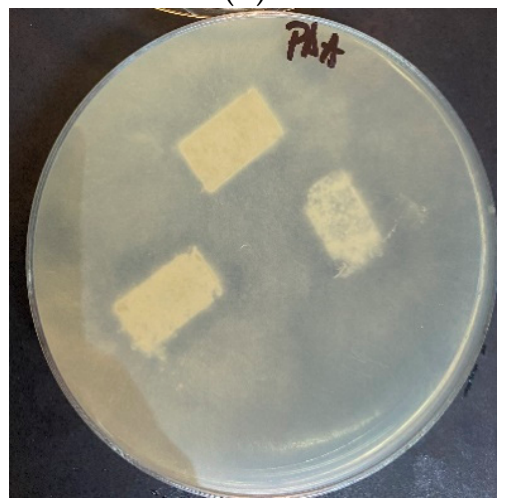

(e)

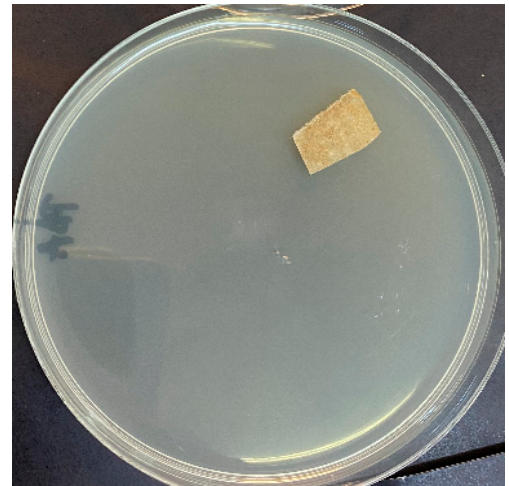

(c)

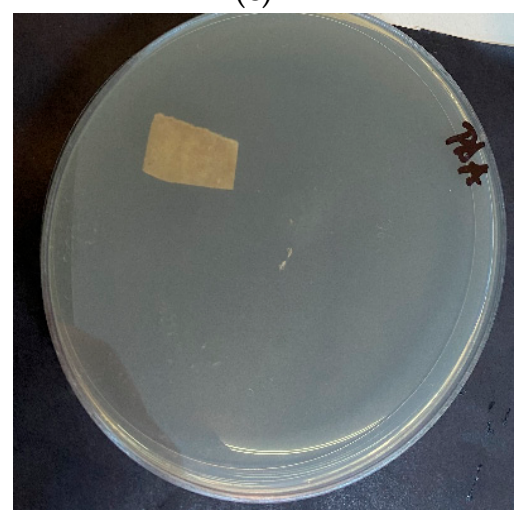

(f)

Figure 14. Aspect of mold cultures obtained in potato dextrose agar (PDA) after three-point inoculation using untreated and ZnO NPs treated old book specimens. Sample A (a,d) paper specimen with microfungi colonization and biodegradation aspect (a-surface; $d$-reverse); sample B (b,e) paper specimen with microfungi colonization and biodegradation aspect (b-surface; e-reverse); sample A_ZnO (c,f) treated paper specimen (c-surface; f-reverse).

Aspergillus sp. and Penicillium sp. are the most important mold geniuses with great implications in human and animal pathology, causing numerous skin and respiratory infections [73].

In Figure 14, it can be observed a combined growth of various filamentous fungi in the untreated old book paper sample A (Figure 14a,d) and a unique microfungal species in the plates where the untreated old paper specimen B (Figure 14b,e) was seeded. In the PDA plates inoculated with ZnO NPs treated old book paper sample A_ZnO (Figure 14c,f), no fungal development has been noticed. Antifungal activity of $\mathrm{ZnO}$ is reported in fewer papers if compared with antibacterial activity. Nevertheless, there are reports of activity against Aspergillus niger [56,74], Trichoderma sp. [75,76] and Penicillium sp. [77,78].

The paper sample A, belonging from a book, was more contaminated than unused manual paper sample B. The reason for this mix of fungal strains, Aspergillus niger, Trichoderma sp. and Penicillium sp., can be related to the fact that the book was handled by users, while the blanc paper was only stored in library.

\section{Conclusions}

$\mathrm{ZnO}$ nanoparticles, obtained by the solvothermal method, are polyhedral shaped, with a $\sim 20 \mathrm{~nm}$ diameter and high crystallinity. The investigation of photocatalytic activity against methylene blue indicated that $\mathrm{ZnO}$ nanopowder has the capacity to degrade both the MB dye monomer and the dimer, 
under visible light irradiation. This high photocatalytic activity imparts a good antimicrobial activity. Indeed, the $\mathrm{ZnO}$ nanopowder exhibited good antibacterial activity against both Gram-positive and Gram-negative strains. The best results were observed against Enterococcus Faecalis (ATCC 44479) and Escherichia coli (ATCC 25922), while the weakest activity was recorded against Pseudomonas aeruginosa (ATCC 27853). This synthesis route allows the obtaining of pure $\mathrm{ZnO}$ at nano scale dimensions, exhibiting antibacterial and antifungal activities dependent of their particle size, surface chemistry, and defects generated as seen also in photocatalytic processes.

Treatment of paper samples from XVIII-XIX century with ZnO nanoparticles indicated that the $\mathrm{ZnO}$ nanopowder can also clean and protect the cellulosic material from fungal infections with Aspergillus niger, Trichoderma sp. and Penicillium sp., strains, present onto untreated paper samples. The optical properties of treated paper were enhanced, and $\mathrm{ZnO}$ can be used as UV-barrier to protect the cellulose from the harmful radiation.

Author Contributions: Conceptualization, F.D., A.-G.R. and L.M.; methodology, L.M., B.-S.V. and O.O.; formal analysis, R.-D.T., A.-M.H. and B.-S.V.; investigation, R.-D.T., A.-M.H. and F.D.; resources, O.O.; data curation, L.M. and A.P.; writing —original draft preparation, L.M. and O.O.; writing—review and editing, A.P. and A.-G.R.; supervision, F.D.; project administration, A.P.; funding acquisition, O.O. All authors have read and agreed to the published version of the manuscript.

Funding: This work was supported by a grant of the Romanian Ministry of Research and Innovation, CCCDI-UEFISCDI, project number PN-III-P1-1.2-PCCDI-2017-0689/P1. "Lib2Life-Revitalizarea bibliotecilor şi a patrimoniului cultural prin tehnologii avansate" within PNCDI III.

Conflicts of Interest: The authors declare no conflict of interest. The funders had no role in the design of the study; in the collection, analyses, or interpretation of data; in the writing of the manuscript, or in the decision to publish the results.

\section{References}

1. Amini, E.; Azadfallah, M. In situ synthesis of silver nanoparticles on fiber matrix for preparing antibacterial paper. Biointerface Res. Appl. Chem. 2018, 8, 3449-3456.

2. Brown, N.; Lichtblau, D.; Fearn, T.; Strlic, M. Characterisation of 19th and 20th century Chinese paper. Herit. Sci. 2017, 5. [CrossRef]

3. Barrett, T.; Ormsby, M.; Lang, J. Non-Destructive Analysis of 14th-19th Century European Handmade Papers. Restaur. Int. J. Preserv. Libr. Arch. Mater. 2016, 37, 93-135. [CrossRef]

4. Area, M.C.; Cheradame, H. Paper Aging and Degradation: Recent Findings and Research Methods. Bioresources 2011, 6, 5307-5337.

5. Flint, H.J.; Scott, K.P.; Duncan, S.H.; Louis, P.; Forano, E. Microbial degradation of complex carbohydrates in the gut. Gut Microbes 2012, 3, 289-306. [CrossRef]

6. Jo, H.J.; Joo, S.M.; Kim, J.Y.; Yu, K.H.; Kim, S.W. Development of a Hybrid Chitosan- and Niacinamide-Coupled ZnO Nanoparticle Composite for Sun Protection Application. J. Nanomater. 2019, 2019. [CrossRef]

7. Nazir, S.; Rabbani, A.; Mehmood, K.; Maqbool, F.; Shah, G.M.; Khan, M.F.; Sajid, M. Antileishmanial activity and cytotoxicity of ZnO-based nano-formulations. Int. J. Nanomed. 2019, 14, 7809-7822. [CrossRef]

8. Nada, A.A.; Selim, H.; Bechelany, M.; El-Sayed, M.; Hegazey, R.M.; Souaya, E.R.; Kotkata, M.F. A novel photoelectrode of NiO@ZnO nanocomposite prepared by Pechini method coupled with PLD for efficiency enhancement in DSSCs. Mater. Sci. 2018, 36, 327-336. [CrossRef]

9. Deyab, M.A.; Nada, A.A.; Hamdy, A. Comparative study on the corrosion and mechanical properties of nano-composite coatings incorporated with $\mathrm{TiO}_{2}$ nano-particles, $\mathrm{TiO}_{2}$ nano-tubes, and $\mathrm{ZnO}$ nano-flowers. Prog. Org. Coat. 2017, 105, 245-251. [CrossRef]

10. Oprea, O.; Andronescu, E.; Ficai, D.; Ficai, A.; Oktar, F.N.; Yetmez, M. ZnO Applications and Challenges. Curr. Org. Chem. 2014, 18, 192-203. [CrossRef]

11. Patino-Herrera, R.; Catarino-Centeno, R.; Robles-Martinez, M.; Zarate, M.G.M.; Flores-Arriaga, J.C.; Perez, E. Antimycotic activity of zinc oxide decorated with silver nanoparticles against Trichophyton mentagrophytes. Powder Technol. 2018, 327, 381-391. [CrossRef] 
12. Wasim, M.; Khan, M.R.; Mushtaq, M.; Naeem, A.; Han, M.C.; Wei, Q.F. Surface Modification of Bacterial Cellulose by Copper and Zinc Oxide Sputter Coating for UV-Resistance/Antistatic/Antibacterial Characteristics. Coatings 2020, 10, 364. [CrossRef]

13. Sabry, N.M.; Tolba, S.T.M.; Abdel-Gawad, F.K.; Bassem, S.M.; Nassar, H.; El-Taweel, G.E.; Ibrahim, M.A. On the molecular modeling analyses of the interaction between nano zinc oxide and bacteria. Biointerface Res. Appl. Chem. 2018, 8, 3294-3297.

14. Husain, $Q$. An overview on the green synthesis of nanoparticles and other nano-materials using enzymes and their potential applications. Biointerface Res. Appl. Chem. 2019, 9, 4255-4271.

15. Vasile, O.R.; Serdaru, I.; Andronescu, E.; Trusca, R.; Surdu, V.A.; Oprea, O.; Ilie, A.; Vasile, B.S. Influence of the size and the morphology of ZnO nanoparticles on cell viability. Comptes Rendus Chim. 2015, 18, 1335-1343. [CrossRef]

16. Tymoszuk, A.; Wojnarowicz, J. Zinc Oxide and Zinc Oxide Nanoparticles Impact on In Vitro Germination and Seedling Growth in Allium cepaL. Materials 2020, 13, 2784. [CrossRef]

17. Taha, A.; Ben Aissa, M.; Da'na, E. Green Synthesis of an Activated Carbon-Supported Ag and ZnO Nanocomposite for Photocatalytic Degradation and Its Antibacterial Activities. Molecules 2020, 25, 1586. [CrossRef]

18. Shi, L.E.; Li, Z.H.; Zheng, W.; Zhao, Y.F.; Jin, Y.F.; Tang, Z.X. Synthesis, antibacterial activity, antibacterial mechanism and food applications of $\mathrm{ZnO}$ nanoparticles: A review. Food Addit. Contam. Part A Chem. Anal. Control Expo. Risk Assess. 2014, 31, 173-186. [CrossRef]

19. McClements, D.J.; Xiao, H. Is nano safe in foods? Establishing the factors impacting the gastrointestinal fate and toxicity of organic and inorganic food-grade nanoparticles. Sci. Food 2017, 1, 6.

20. Lee, C.C.; Lin, Y.H.; Hou, W.C.; Li, M.H.; Chang, J.W. Exposure to ZnO/TiO 2 Nanoparticles Affects Health Outcomes in Cosmetics Salesclerks. Int. J. Environ. Res. Public Health 2020, 17, 6088. [CrossRef]

21. Motelica, L.; Ficai, D.; Ficai, A.; Oprea, O.C.; Kaya, D.A.; Andronescu, E. Biodegradable Antimicrobial Food Packaging: Trends and Perspectives. Foods 2020, 9, 1438. [CrossRef] [PubMed]

22. Vasile, B.S.; Oprea, O.; Voicu, G.; Ficai, A.; Andronescu, E.; Teodorescu, A.; Holban, A. Synthesis and characterization of a novel controlled release zinc oxide/gentamicin-chitosan composite with potential applications in wounds care. Int. J. Pharm. 2014, 463, 161-169. [CrossRef] [PubMed]

23. Sahu, D.; Kannan, G.M.; Vijayaraghavan, R.; Anand, T.; Khanum, F. Nanosized zinc oxide induces toxicity in human lung cells. ISRN Toxicol. 2013, 2013, 316075. [CrossRef] [PubMed]

24. Sruthi, S.; Ashtami, J.; Mohanan, P.V. Biomedical application and hidden toxicity of Zinc oxide nanoparticles. Mater. Today Chem. 2018, 10, 175-186. [CrossRef]

25. Vandebriel, R.J.; De Jong, W.H. A review of mammalian toxicity of ZnO nanoparticles. Nanotechnol. Sci. Appl. 2012, 5, 61-71. [CrossRef]

26. El Shemy, M.A.; Azab, N.I.; Salim, R.F. Zinc Oxide Nanoparticles: The Hidden Danger. Int. J. Biochem. Biophys. Mol. Biol. 2017, 2, 1-9. [CrossRef]

27. Mohammed, Y.H.; Holmes, A.; Haridass, I.N.; Sanchez, W.Y.; Studier, H.; Grice, J.E.; Benson, H.A.E.; Roberts, M.S. Support for the Safe Use of Zinc Oxide Nanoparticle Sunscreens: Lack of Skin Penetration or Cellular Toxicity after Repeated Application in Volunteers. J. Investig. Dermatol. 2019, 139, 308-315. [CrossRef]

28. Wright, P.; Jackson, N. Safety of engineered nanomaterials and occupational health and safety issues for commercial scale production. In Handbook of Clinical Nanomedicine: Law, Business, Regulation, Safety, and Risk; Bawa, R., Audette, G., Reese, B., Eds.; Pan Stanford Publishing: Singapore, 2016; pp. 569-619.

29. Reshma, V.G.; Mohanan, P.V. Cellular interactions of zinc oxide nanoparticles with human embryonic kidney (HEK 293) cells. Colloids Surf. B 2017, 157, 182-190.

30. Feltis, B.N.; OKeefe, S.J.; Harford, A.J.; Piva, T.J.; Turney, T.W.; Wright, P.F.A. Independent cytotoxic and inflammatory responses to zinc oxide nanoparticles in human monocytes and macrophages. Nanotoxicology 2012, 6, 757-765. [CrossRef]

31. Alaraby, M.; Annangi, B.; Hernandez, A.; Creus, A.; Marcos, R. A comprehensive study of the harmful effects of $\mathrm{ZnO}$ nanoparticles using Drosophila melanogaster as an in vivo model. J. Hazard. Mater. 2015, 296, 166-174. [CrossRef]

32. Wright, P.F.A. Realistic Exposure Study Assists Risk Assessments of ZnO Nanoparticle Sunscreens and Allays Safety Concerns. J. Investig. Dermatol. 2019, 139, 277-278. [CrossRef] [PubMed] 
33. Oprea, O.; Andronescu, E.; Vasile, B.S.; Voicu, G.; Covaliu, C. Synthesis and Characterization of Zno Nanopowder by Non-Basic Route. Dig. J. Nanomater. Biostruct. 2011, 6, 1393-1401.

34. Anuar, M.F.; Fen, Y.W.; Zaid, M.H.M.; Omar, N.A.S.; Khaidir, R.E.M. Sintering Temperature Effect on Structural and Optical Properties of Heat Treated Coconut Husk Ash Derived $\mathrm{SiO}_{2}$ Mixed with $\mathrm{ZnO}$ Nanoparticles. Materials 2020, 13, 2555. [CrossRef] [PubMed]

35. Beitollahi, H.; Tajik, S.; Nejad, F.G.; Safaei, M. Recent advances in ZnO nanostructure-based electrochemical sensors and biosensors. J. Mater. Chem. B 2020, 8, 5826-5844. [CrossRef]

36. Amakali, T.; Daniel, L.S.; Uahengo, V.; Dzade, N.Y.; de Leeuw, N.H. Structural and Optical Properties of ZnO Thin Films Prepared by Molecular Precursor and Sol-Gel Methods. Crystals 2020, 10, 132. [CrossRef]

37. Abderrahmane, B.; Djamila, A.; Chaabia, N.; Fodil, R. Improvement of ZnO nanorods photoelectrochemical, optical, structural and morphological characterizations by cerium ions doping. J. Alloys Compd. 2020, 829, 154498. [CrossRef]

38. Vasile, B.S.; Vasile, O.R.; Ghitulica, D.C.; Ilie, F.C.; Nicoara, I.F.; Trusca, R.; Oprea, O.C.; Surdu, V.A.; Neacsu, I.A. $\mathrm{Eu}^{3+}$-doped $\mathrm{ZnO}$ nanostructures: Advanced characterizations, photoluminescence and cytotoxic effect. Rom. J. Morphol. Embryol. 2017, 58, 941-952.

39. Khranovskyy, V.; Lazorenko, V.; Lashkarev, G.; Yakimova, R. Luminescence anisotropy of ZnO microrods. J. Lumin. 2012, 132, 2643-2647. [CrossRef]

40. Galdamez-Martinez, A.; Santana, G.; Guell, F.; Martinez-Alanis, P.R.; Dutt, A. Photoluminescence of ZnO Nanowires: A Review. Nanomaterials 2020, 10, 857. [CrossRef]

41. Munoz-Aguirre, N.; Martinez-Perez, L.; Munoz-Aguirre, S.; Flores-Herrera, L.A.; Hernandez, E.V.; Zelaya-Angel, O. Luminescent Properties of (004) Highly Oriented Cubic Zinc Blende ZnO Thin Films. Materials 2019, 12, 3314. [CrossRef]

42. Zhang, M.; Averseng, F.; Krafft, J.M.; Borghetti, P.; Costentin, G.; Stankic, S. Controlled Formation of Native Defects in Ultrapure ZnO for the Assignment of Green Emissions to Oxygen Vacancies. J. Phys. Chem. C 2020, 124, 12696-12704. [CrossRef]

43. Janotti, A.; Van de Walle, C.G. Native point defects in ZnO. Phys. Rev. B 2007, 76, 165202. [CrossRef]

44. Oprea, O.; Vasile, O.R.; Voicu, G.; Andronescu, E. The Influence of the Thermal Treatment on Luminescence Properties of Zno. Dig. J. Nanomater. Biostruct. 2013, 8, 747-756.

45. Vaja, F.; Comanescu, C.; Oprea, O.; Ficai, D.; Guran, C. Effects of ZnO Nanoparticles on the Wet Scrub Resistance and Photocatalytic Properties of Acrylic Coatings. Revista De Chimie 2012, 63, 722-726.

46. Oprea, O.; Vasile, O.R.; Voicu, G.; Craciun, L.; Andronescu, E. Photoluminescence, Magnetic Properties and Photocatalytic Activity of $\mathrm{Gd}^{3+}$ Doped Zno Nanoparticles. Dig. J. Nanomater. Biostruct. 2012, 7, 1757-1766.

47. Voicu, G.; Oprea, O.; Vasile, B.S.; Andronescu, E. Photoluminescence and Photocatalytic Activity of Mn-Doped Zno Nanoparticles. Dig. J. Nanomater. Biostruct. 2013, 8, 667-675.

48. Nada, A.A.; Tantawy, H.R.; Elsayed, M.A.; Bechelany, M.; Elmowafy, M.E. Elaboration of nano titania-magnetic reduced graphene oxide for degradation of tartrazine dye in aqueous solution. Solid State Sci. 2018, 78, 116-125. [CrossRef]

49. Nada, A.A.; El Rouby, W.M.A.; Bekheet, M.F.; Antuch, M.; Weber, M.; Miele, P.; Viter, R.; Roualdes, S.; Millet, P.; Bechelany, M. Highly textured boron/nitrogen co-doped $\mathrm{TiO}_{2}$ with honeycomb structure showing enhanced visible-light photoelectrocatalytic activity. Appl. Surf. Sci. 2020, 505, 144419. [CrossRef]

50. Blazeka, D.; Car, J.; Klobucar, N.; Jurov, A.; Zavasnik, J.; Jagodar, A.; Kovacevic, E.; Krstulovic, N. Photodegradation of Methylene Blue and Rhodamine B Using Laser-Synthesized ZnO Nanoparticles. Materials 2020, 13, 4357. [CrossRef]

51. Iqbal, A.; Ibrahim, N.H.; Rahman, N.R.A.; Saharudin, K.A.; Adam, F.; Sreekantan, S.; Yusop, R.M.; Jaafar, N.F.; Wilson, L.D. ZnO Surface Doping to Enhance the Photocatalytic Activity of Lithium Titanate/TiO $\mathrm{T}_{2}$ for Methylene Blue Photodegradation under Visible Light Irradiation. Surfaces 2020, 3, 301-318. [CrossRef]

52. Vinayagam, R.; Selvaraj, R.; Arivalagan, P.; Varadavenkatesan, T. Synthesis, characterization and photocatalytic dye degradation capability of Calliandra haematocephala-mediated zinc oxide nanoflowers. J. Photochem. Photobiol. B Biol. 2020, 203, 111760. [CrossRef] [PubMed]

53. Yu, Y.; Yao, B.H.; He, Y.Q.; Cao, B.Y.; Ma, W.; Chang, L.L. Oxygen defect-rich In-doped ZnO nanostructure for enhanced visible light photocatalytic activity. Mater. Chem. Phys. 2020, 244, 122672. [CrossRef] 
54. Zgura, I.; Preda, N.; Enculescu, M.; Diamandescu, L.; Negrila, C.; Bacalum, M.; Ungureanu, C.; Barbinta-Patrascu, M.E. Cytotoxicity, Antioxidant, Antibacterial, and Photocatalytic Activities of ZnO-CdS Powders. Materials 2020, 13, 182. [CrossRef] [PubMed]

55. Viswanathan, K.; Kim, I.; Kasi, G.; Sadeghi, K.; Thanakkasaranee, S.; Seo, J. Facile approach to enhance the antibacterial activity of ZnO nanoparticles. Adv. Appl. Ceram. 2020, 119, 414-422. [CrossRef]

56. Ibrahim, N.A.; Nada, A.A.; Hassabo, A.G.; Eid, B.M.; El-Deen, A.M.; Abou-Zeid, N.Y. Effect of different capping agents on physicochemical and antimicrobial properties of ZnO nanoparticles. Chem. Pap. 2017, 71, 1365-1375. [CrossRef]

57. Zhao, Y.J.; Zhang, C.X.; Folly, Y.M.E.; Chang, J.H.; Wang, Y.; Zhou, L.; Zhang, H.P.; Liu, Y. Morphological and Transcriptomic Analysis of the Inhibitory Effects of Lactobacillus plantarum on Aspergillus flavus Growth and Aflatoxin Production. Toxins 2019, 11, 636. [CrossRef]

58. Jeong, M.J.; Kang, K.Y.; Bacher, M.; Kim, H.J.; Jo, B.M.; Potthast, A. Deterioration of ancient cellulose paper, Hanji: Evaluation of paper permanence. Cellulose 2014, 21, 4621-4632. [CrossRef]

59. Kubovsky, I.; Kacikova, D.; Kacik, F. Structural Changes of Oak Wood Main Components Caused by Thermal Modification. Polymers 2020, 12, 485. [CrossRef]

60. Lemnaru, G.M.; Trusca, R.D.; Ilie, C.I.; Tiplea, R.E.; Ficai, D.; Oprea, O.; Stoica-Guzun, A.; Ficai, A.; Ditu, L.M. Antibacterial Activity of Bacterial Cellulose Loaded with Bacitracin and Amoxicillin: In Vitro Studies. Molecules 2020, 25, 4069. [CrossRef]

61. Motelica, L.; Craciun, L.; Ardelean, I.; Ioana, M.V. Non-destructive Analyses of 16th Century Documents. Revista De Chimie 2019, 70, 2798-2802. [CrossRef]

62. Oyewo, O.A.; Adeniyi, A.; Sithole, B.B.; Onyango, M.S. Sawdust-Based Cellulose Nanocrystals Incorporated with $\mathrm{ZnO}$ Nanoparticles as Efficient Adsorption Media in the Removal of Methylene Blue Dye. ACS Omega 2020, 5, 18798-18807. [CrossRef] [PubMed]

63. Zhang, X.L.; Ren, S.X.; He, X.F.; Dong, L.L.; Bai, W.; Lei, T.Z.; Chen, H. Preparation and Characterization of Cellulose Nanofiber/Zinc Oxide Composite Films. J. Biobased Mater. Bioenergy 2020, 14, 203-208. [CrossRef]

64. Cole, C.G.B.; Roberts, J.J. The fluorescence of gelatin and its implications. Imaging Sci. J. 1997, 45, 145-149. [CrossRef]

65. Cai, B.; Rao, L.; Ji, X.H.; Bu, L.L.; He, Z.B.; Wan, D.; Yang, Y.; Liu, W.; Guo, S.S.; Zhao, X.Z. Autofluorescent gelatin nanoparticles as imaging probes to monitor matrix metalloproteinase metabolism of cancer cells. J. Biomed. Mater. Res. A 2016, 104, 2854-2860. [CrossRef]

66. Malinowska, K.H.; Rind, T.; Verdorfer, T.; Gaub, H.E.; Nash, M.A. Quantifying Synergy, Thermostability, and Targeting of Cellulolytic Enzymes and Cellulosomes with Polymerization-Based Amplification. Anal. Chem. 2015, 87, 7133-7140. [CrossRef]

67. Yuan, W.Z.; Zhang, Y.M. Nonconventional Macromolecular Luminogens with Aggregation-Induced Emission Characteristics. J. Polym. Sci. A Polym. Chem. 2017, 55, 560-574. [CrossRef]

68. Teixeira, F.J.; Castro, A.A.N.; Sant'Ana, A.C. Investigating the origin of the raw material of rag paper by Raman spectroscopy. Vib. Spectrosc. 2018, 98, 119-122. [CrossRef]

69. Agarwal, U.P. Analysis of Cellulose and Lignocellulose Materials by Raman Spectroscopy: A Review of the Current Status. Molecules 2019, 24, 1659. [CrossRef]

70. Castellan, A.; Ruggiero, R.; Frollini, E.; Ramos, L.A.; Chirat, C. Studies on fluorescence of cellulosics. Holzforschung 2007, 61, 504-508. [CrossRef]

71. Fu, F.Y.; Li, L.Y.; Liu, L.J.; Cai, J.; Zhang, Y.P.; Zhou, J.P.; Zhang, L.N. Construction of Cellulose Based ZnO Nanocomposite Films with Antibacterial Properties through One-Step Coagulation. ACS Appl. Mater. Interfaces 2015, 7, 2597-2606. [CrossRef]

72. Awan, F.; Islam, M.S.; Ma, Y.Y.; Yang, C.; Shi, Z.Q.; Berry, R.M.; Tam, K.C. Cellulose Nanocrystal-ZnO Nanohybrids for Controlling Photocatalytic Activity and UV Protection in Cosmetic Formulation. ACS Omega 2018, 3, 12403-12411. [CrossRef] [PubMed]

73. Egbuta, M.A.; Mwanza, M.; Babalola, O.O. Health Risks Associated with Exposure to Filamentous Fungi. Int. J. Environ. Res. Public Health 2017, 14, 719. [CrossRef] [PubMed]

74. El-Feky, O.M.; Hassan, E.A.; Fadel, S.M.; Hassan, M.L. Use of ZnO nanoparticles for protecting oil paintings on paper support against dirt, fungal attack, and UV aging. J. Cult. Herit. 2014, 15, 165-172. [CrossRef] 
75. Chen, J.B.; Ma, Y.Y.; Lin, H.P.; Zheng, Q.Z.; Zhang, X.X.; Yang, W.B.; Li, R. Fabrication of Hydrophobic $\mathrm{ZnO} / \mathrm{PMHS}$ Coatings on Bamboo Surfaces: The Synergistic Effect of ZnO and PMHS on Anti-Mildew Properties. Coatings 2019, 9, 15. [CrossRef]

76. Luo, Z.W.; Zhu, M.; Guo, M.L.; Lian, Z.Y.; Tong, W.; Wang, J.R.; Zhang, B.H.; Wei, W.J. Ultrasonic-Assisted Dispersion of ZnO Nanoparticles and Its Inhibition Activity to Trichoderma viride. J. Nanosci. Nanotechnol. 2018, 18, 2352-2360. [CrossRef]

77. Wang, J.; Li, J.P.; Zhuang, X.W.; Pan, X.; Yu, H.X.; Sun, F.L.; Song, J.G.; Jin, C.D.; Jiang, Y.T. Improved mould resistance and antibacterial activity of bamboo coated with ZnO/graphene. R. Soc. Open Sci. 2018, 5, 180173. [CrossRef]

78. Ren, D.J.; Li, J.P.; Bao, Y.J.; Wu, Z.X.; He, S.; Wang, A.K.; Guo, F.; Chen, Y.H. Low-temperature synthesis of flower-like $\mathrm{ZnO}$ microstructures supported on $\mathrm{TiO}_{2}$ thin films as efficient antifungal coatings for bamboo protection under dark conditions. Colloids Surf. A Physicochem. Eng. Asp. 2018, 555, 381-388. [CrossRef]

Publisher's Note: MDPI stays neutral with regard to jurisdictional claims in published maps and institutional affiliations.

(C) 2020 by the authors. Licensee MDPI, Basel, Switzerland. This article is an open access article distributed under the terms and conditions of the Creative Commons Attribution (CC BY) license (http://creativecommons.org/licenses/by/4.0/). 